Atmos. Chem. Phys., 18, 13925-13945, 2018

https://doi.org/10.5194/acp-18-13925-2018

(C) Author(s) 2018. This work is distributed under

the Creative Commons Attribution 4.0 License.

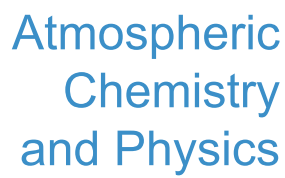

(c) (P)

\title{
Seasonal ozone vertical profiles over North America using the AQMEII3 group of air quality models: model inter-comparison and stratospheric intrusions
}

\author{
Marina Astitha ${ }^{1}$, Ioannis Kioutsioukis ${ }^{2}$, Ghezae Araya Fisseha ${ }^{1}$, Roberto Bianconi ${ }^{3}$, Johannes Bieser ${ }^{4,5}$, \\ Jesper H. Christensen ${ }^{6}$, Owen R. Cooper ${ }^{7,8}$, Stefano Galmarini ${ }^{9}$, Christian Hogrefe ${ }^{10}$, Ulas Im $^{6}$, Bryan Johnson ${ }^{7}$, \\ Peng Liu ${ }^{11}$, Uarporn Nopmongcol ${ }^{12}$, Irina Petropavlovskikh ${ }^{7}$, Efisio Solazzo ${ }^{9}$, David W. Tarasick ${ }^{13}$, and \\ Greg Yarwood ${ }^{12}$ \\ ${ }^{1}$ University of Connecticut, Civil and Environmental Engineering, Storrs, CT 06269-3037, USA \\ ${ }^{2}$ University of Patras, Physics Department, 26504 Rio, Greece \\ ${ }^{3}$ Enviroware srl, via Dante 142, 20863 Concorezzo, Italy \\ ${ }^{4}$ Helmholtz-Zentrum Geesthacht, Institute of Coastal Research, Geesthacht, Germany \\ ${ }^{5}$ German Aerospace Center (DLR), National Aeronautics and Space Center, Weßling, Germany \\ ${ }^{6}$ Aarhus University, Department of Environmental Science, Frederiksborgvej 399, 4000 Roskilde, Denmark \\ ${ }^{7}$ Cooperative Institute for Research in Environmental Sciences, University of Colorado, Boulder, CO 80309, USA \\ ${ }^{8}$ Chemical Sciences Division, NOAA Earth System Research Laboratory, Boulder, CO 80305, USA \\ ${ }^{9}$ European Commission Joint Research Center, Ispra, Italy \\ ${ }^{10}$ Environmental Protection Agency Research Triangle Park, Research Triangle Park, NC, USA \\ ${ }^{11}$ NRC Fellowship Participant at Environmental Protection Agency Research Triangle Park, NC, USA \\ ${ }^{12}$ Ramboll, 773 San Marin Dr., Suite 2115, Novato, CA 94945, USA \\ ${ }^{13}$ Air Quality Research Division, Environment and Climate Change Canada, Downsview, Ontario, Canada
}

Correspondence: Marina Astitha (astitha@engr.uconn.edu)

Received: 30 January 2018 - Discussion started: 23 February 2018

Revised: 4 August 2018 - Accepted: 9 August 2018 - Published: 2 October 2018

\begin{abstract}
This study evaluates simulated vertical ozone profiles produced in the framework of the third phase of the Air Quality Model Evaluation International Initiative (AQMEII3) against ozonesonde observations in North America for the year 2010. Four research groups from the United States (US) and Europe have provided modeled ozone vertical profiles to conduct this analysis. Because some of the modeling systems differ in their meteorological drivers, wind speed and temperature are also included in the analysis. In addition to the seasonal ozone profile evaluation for 2010, we also analyze chemically inert tracers designed to track the influence of lateral boundary conditions on simulated ozone profiles within the modeling domain. Finally, cases of stratospheric ozone intrusions during May-June 2010 are investigated by analyzing ozonesonde measurements and the corresponding model simulations at Intercontinental Chemical Transport Experiment Ozonesonde Network Study (IONS)
\end{abstract}

experiment sites in the western United States. The evaluation of the seasonal ozone profiles reveals that, at a majority of the stations, ozone mixing ratios are underestimated in the $1-6 \mathrm{~km}$ range. The seasonal change noted in the errors follows the one seen in the variance of ozone mixing ratios, with the majority of the models exhibiting less variability than the observations. The analysis of chemically inert tracers highlights the importance of lateral boundary conditions up to $250 \mathrm{hPa}$ for the lower-tropospheric ozone mixing ratios $(0$ $2 \mathrm{~km}$ ). Finally, for the stratospheric intrusions, the models are generally able to reproduce the location and timing of most intrusions but underestimate the magnitude of the maximum mixing ratios in the $2-6 \mathrm{~km}$ range and overestimate ozone up to the first kilometer possibly due to marine air influences that are not accurately described by the models. The choice of meteorological driver appears to be a greater predictor of 
model skill in this altitude range than the choice of air quality model.

\section{Introduction}

Since its initiation in 2008, the Air Quality Model Evaluation International Initiative (AQMEII) has brought together scientists from both sides of the North Atlantic Ocean to perform regional model experiments using common boundary conditions, emissions and model evaluation frameworks with a specific focus on regional modeling domains over Europe and North America (Galmarini and Rao, 2011; Rao et al., 2012; Galmarini et al., 2017). Phase 3 of the AQMEII activities (AQMEII3) focuses on joint modeling experiments with the second phase of the Task Force on Hemispheric Transport of Air Pollution (TF-HTAP) to conduct global and regional assessments of intercontinental transport of air pollutants (Huang et al., 2017; Nopmongcol et al., 2017) and uncertainties stemming from emissions and boundary conditions (Huang et al., 2017; Hogrefe et al., 2018). Investigation of the vertical ozone distribution has occurred during previous phases of the AQMEII activities (Schere et al., 2012; Solazzo et al., 2013) but with model simulations that vary in emissions and boundary conditions for different years. The motivation behind this work is that in AQMEII3 common anthropogenic emission inventories and lateral chemical boundary conditions were implemented by all modeling groups, which helps us further investigate model-to-model variability and performance evaluation.

Regional air quality model evaluation is most commonly performed for ground-level ozone mixing ratios (Hogrefe et al., 2001; Appel et al., 2007, 2012; Herwehe et al., 2011; Solazzo et al., 2012; Kioutsioukis and Galmarini, 2014; Kioutsioukis et al., 2016; Im et al., 2015, 2018, among others) and less frequently for free tropospheric ozone distributions in longer, non-episodic time frames (Schere et al., 2012; Solazzo et al., 2013; Jonson et al., 2010, using HTAP global modeling systems). This is mainly due to the scarcity of upper-air measurements as well as the need to investigate the efficacy of emission reduction policies and attainment demonstration which apply to surface ozone exceedances. Previous studies related to AQMEII phases 1 and 2 have used measurements from ozonesonde networks and instrumented commercial airliners as part of the Measurement of Ozone and Water Vapor by Airbus In-Service Aircraft (MOZAIC) program (Solazzo et al., 2013; Giordano et al., 2015). Accurate representation of the entire troposphere in air quality models influences the prediction of air pollutant vertical distributions, stratosphere-troposphere exchange processes and ground-level mixing ratios. The AQMEII3 framework is ideal for providing the platform and collaborations to assess multi-model simulated ozone vertical profiles from the ground up to the planetary boundary layer (PBL) and evalu- ate the models' capability to reproduce ozone mixing ratios aloft as well as to assess contributions from boundary conditions (inert tracer experiments) which have important effects on surface and upper-air ozone mixing ratios (Tarasick et al., 2007; Pendlebury et al., 2017).

This study utilizes modeling results for the North American domain from four research groups that participated in AQMEII3 to evaluate seasonal ozone vertical profiles simulated for the year 2010 against ozonesonde observations. The objectives of this analysis are to (a) evaluate simulated seasonal ozone vertical profiles with ozonesonde measurements, (b) assess variations in model performance related to ozone vertical distribution (model inter-comparison), (c) assess influence of lateral boundary conditions to ozone profiles within the modeling domain, and (d) investigate cases of stratospheric ozone intrusion above the western United States during May and June 2010. Because some of the modeling systems differ in their meteorological drivers, available wind speed and temperature are also included in the evaluation. In addition to the ozone profile evaluation for 2010, we analyze chemically inert tracer modeling experiments that estimated the influence of lateral boundary conditions to ozone profiles within the modeling domain. Finally, several cases of stratospheric ozone intrusions are investigated by analyzing ozonesonde measurements and the corresponding model simulations at Intercontinental Chemical Transport Experiment Ozonesonde Network Study (IONS) experiment sites in the western United States (Cooper et al., 2011, 2012). IONS2010 was a component of the CalNex (Research at the Nexus of Air Quality and Climate Change) 2010 experiment, which focused on understanding the effects of air pollutants on air quality across California (Ryerson et al., 2013). The data and methods of analysis are described in Sect. 2, the evaluation and model inter-comparison of ozone seasonal profiles are provided in Sect. 3, the results from the model experiments using chemically inert tracers are provided in Sect. 4 and the case study of stratospheric ozone intrusions is discussed in Sect. 5. The summary and conclusions are presented in Sect. 6.

\section{Data and methods}

\subsection{Atmospheric modeling systems}

The base case simulations used in this study are performed by all AQMEII3 participants using lateral chemical boundary conditions prepared from global concentration fields simulated by ECMWF's global chemistry model C-IFS (Flemming et al., 2015). Table 1 provides an overview of each participating research group or institution, their modeling systems and the main specifications of the simulations. A detailed description of the four modeling systems (US1, US3, DE1 and DK1) is provided in Solazzo et al. (2017). Harmonization of all model simulations is achieved by specifying a 
Table 1. Specifications of the modeling systems used in this study. All models use chemical boundary conditions from C-IFS (see notes). The common North American analysis domain has the following extent: 130 to $59.5^{\circ} \mathrm{W}, 23.5$ to $58.5^{\circ} \mathrm{N}$.

\begin{tabular}{|c|c|c|c|c|c|c|c|}
\hline Institution & Abbreviation & Modeling systems & $\begin{array}{l}\text { Boundary conditions } \\
\text { (meteo) }\end{array}$ & $\begin{array}{l}\text { Horizontal grid } \\
\text { spacing }\end{array}$ & $\begin{array}{l}\text { Vertical } \\
\text { layers }\end{array}$ & $\begin{array}{l}\text { Approximate height } \\
\text { at first layer }\end{array}$ & $\begin{array}{l}\text { Inert } \\
\text { tracers }\end{array}$ \\
\hline U.S. EPA & US3 & WRF3.4/CMAQ5.0.2 & NCEP & $12 \mathrm{~km}$ & $\begin{array}{l}35 \text { layers } \\
\text { up to } \\
50 \mathrm{hPa}\end{array}$ & $19 \mathrm{~m}$ & Yes \\
\hline $\begin{array}{l}\text { Helmholtz- } \\
\text { Zentrum } \\
\text { Geesthacht } \\
\text { (Germany) }\end{array}$ & DE1 & COSMO-CLM/CMAQ5.0.1 & NCEP & $24 \mathrm{~km}$ & $\begin{array}{l}30 \text { layers } \\
\text { up to } \\
50 \mathrm{hPa}\end{array}$ & $40 \mathrm{~m}$ & Yes \\
\hline Ramboll (US) & US1 & WRF3.4/CAMx6.2 & NCEP & $12 \mathrm{~km}$ & $\begin{array}{l}26 \text { layers } \\
\text { up to } \\
97.5 \mathrm{hPa}\end{array}$ & $19 \mathrm{~m}$ & No \\
\hline $\begin{array}{l}\text { Aarhus Univer- } \\
\text { sity (Denmark) }\end{array}$ & DK1 & WRF/DEHM & ECMWF & $16.7 \mathrm{~km}$ & $\begin{array}{l}29 \text { layers } \\
\text { up to } \\
100 \mathrm{hPa}\end{array}$ & $25 \mathrm{~m}$ & Yes \\
\hline
\end{tabular}

common simulation time period (January-December 2010), common regional anthropogenic and fire emission inventories that include emissions for Canada and Mexico (details on the emission inventories is provided in Pouliot et al., 2015), and common lateral chemical boundary conditions. The 2008 National Emission Inventory is used as basis for the 2010 emissions with necessary updates described in Pouliot et al. (2015). Anthropogenic emissions totals are the same for all models, but each group uses their own system to spatially disaggregate and temporally allocate emissions to their gridded domain (for example, DE1 and DK1 use HTAP emissions while US3 and US1 use the Sparse Matrix Operator Kernel Emissions, SMOKE; SMOKE emissions were provided on an hourly basis while HTAP is monthly, so the temporal, vertical and chemical distributions might be different among models). The simulations differ in the modeling systems (air quality and meteorology), horizontal and vertical grid spacing, chemistry modules and deposition schemes as well as biogenic emissions. Each modeling group was free to use the meteorological model of their choice based on compatibility with their chemical transport model. More details on the AQMEII3 modeling experiments are included in the technical note by Galmarini et al. (2017). All research groups interpolated their results into the same $0.25 \times 0.25^{\circ}$ grid spacing before submitting the model outputs to the common data platform for the analysis (Joint Research Institute's ENSEMBLE system).

Each modeling group also included three non-reactive tracers in their simulations but only three of the four models provided 3-D output of the tracer concentrations (Table 1). These tracers are designed to track the inflow of ozone from the lateral domain boundaries and are specified as lateral boundary conditions, with no emissions or chemical formation/destruction occurring within the modeling domain. All tracers undergo advection, diffusion, cloud mixing/transport, scavenging and deposition, but no chemistry. The tracer mixing ratios and their vertical profiles are used to investigate the sensitivity of ozone to the lateral boundary conditions. It should be noted that these inert tracers were not intended to provide a quantitative attribution of ground-level ozone to ozone boundary conditions. As noted by Baker et al. (2015) and Nopmongcol et al. (2017), inert tracers would overestimate such contributions due to the lack of chemical loss terms which are considered in other attribution tools such as reactive tracers or ozone source apportionment. However, using them in a relative manner helps identify the sensitivity of modeled ozone mixing ratios to lateral boundary conditions. The definition of each tracer is as follows:

1. BC1: for layers below $750 \mathrm{hPa}(\sim 2.5 \mathrm{~km})$, the boundary conditions for this tracer are set to the same C-IFS ozone mixing ratios used as ozone boundary conditions for the regional models. For layers above $750 \mathrm{hPa}$, the boundary conditions for this tracer are set to zero.

2. $\mathrm{BC} 2$ : for layers between $750 \mathrm{hPa}(\sim 2.5 \mathrm{~km})$ and $250 \mathrm{hPa}(\sim 10 \mathrm{~km})$, the boundary conditions for this tracer are set to the same C-IFS ozone mixing ratios used as ozone boundary conditions for the regional models. For layers below 750 and above $250 \mathrm{hPa}$, the boundary conditions are set to zero.

3. BC3: for layers above $250 \mathrm{hPa}(\sim 10 \mathrm{~km})$, the boundary conditions for this tracer are set to the same C-IFS ozone mixing ratios used as ozone boundary conditions for the regional models. For layers below $250 \mathrm{hPa}$, the boundary conditions are set to zero. 

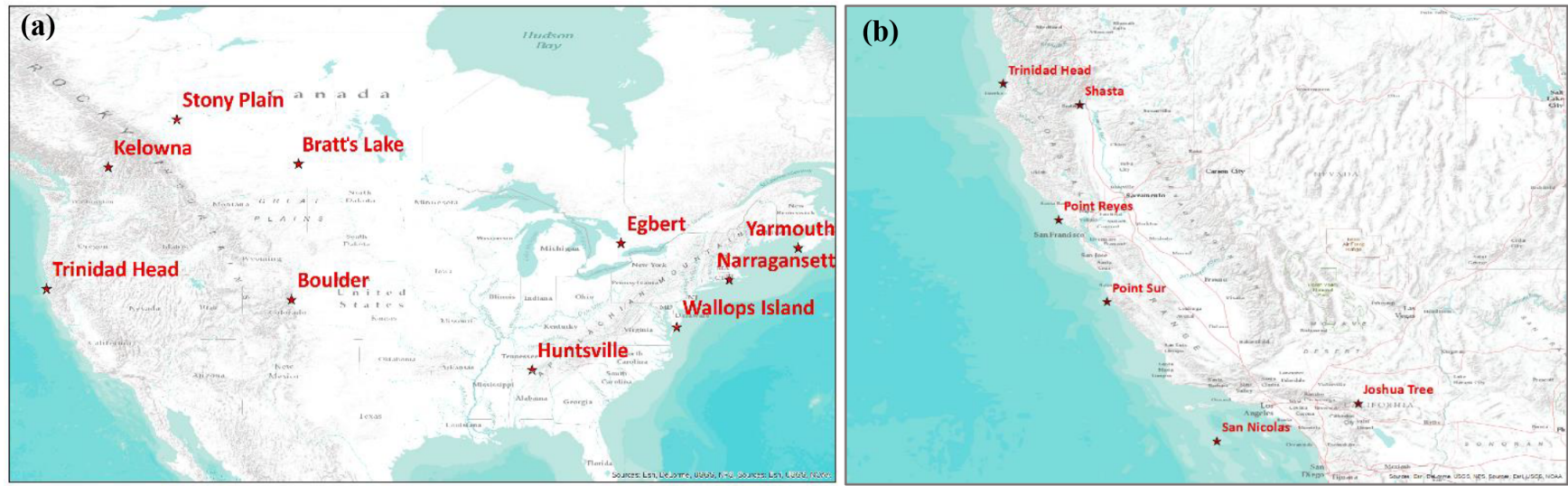

Figure 1. Geographic maps of ozonesonde monitoring sites for 2010: (a) North America (seasonal analysis) and (b) western United States (stratospheric intrusion evaluation).

Table 2. Names, codes and geographic locations of ozonesonde sites. Next to the code is a characterization of the site location relative to the model domain. The elevation at these sites ranges from sea level to $1.6 \mathrm{~km}$ above sea level.

\begin{tabular}{|c|c|c|c|c|c|c|}
\hline ID & Code & Name & Longitude & Latitude & Network & Number of profiles \\
\hline 1 & STN021/north & Stony Plain & -114.1 & 53.54 & ECCC & 43 \\
\hline 2 & STN107/east & Wallops Island & -75.47 & 37.93 & NASA-WFF & 53 \\
\hline 3 & STN338/north & Bratt's Lake & -104.7 & 50.20 & ECCC & 49 \\
\hline 4 & STN418/south & Huntsville & -86.64 & 34.72 & NOAA-ESRL & 51 \\
\hline 5 & STN445/west & Trinidad Head & -124.16 & 40.80 & NOAA-ESRL & 77 \\
\hline 6 & STN456/north & Egbert & -79.78 & 44.23 & ECCC & 54 \\
\hline 7 & STN457/west & Kelowna & -119.4 & 49.94 & ECCC & 74 \\
\hline 8 & STN458/east & Yarmouth & -66.1 & 43.87 & ECCC & 70 \\
\hline 9 & STN487/east & Narragansett & -71.42 & 41.49 & NOAA-ESRL & 26 \\
\hline 10 & BOULDER/central & Boulder & -105.25 & 40.00 & NOAA-ESRL & 44 \\
\hline 11 & RY/west & Point Reyes & -122.95 & 38.09 & IONS2010 & 32 \\
\hline 12 & PS/west & Point Sur & -121.89 & 36.30 & IONS2010 & 36 \\
\hline 13 & SN/west & San Nicolas Island & -119.49 & 33.26 & IONS2010 & 23 \\
\hline 14 & JT/west & Joshua Tree & -116.39 & 34.08 & IONS2010 & 36 \\
\hline 15 & $\mathrm{SH} /$ west & Shasta & -122.49 & 40.60 & IONS2010 & 33 \\
\hline
\end{tabular}

Notes: NOAA-ESRL: National Oceanic and Atmospheric Administration Earth System Research Laboratory (data downloaded from https://www.esrl.noaa.gov/, May 2016); NASA-WFF: National Aeronautic and Space Agency Wallops Flight Facility; ECCC: Environment and Climate Change Canada; IONS: Intercontinental Chemical Transport Experiment Ozonesonde Network Study. Data from ECCC and NASA-WFF were downloaded from the WMO World Ozone and Ultraviolet Data Centre (WOUDC; https://doi.org/10.14287/10000001).

\subsection{Ozonesonde sites and statistical metrics}

Ozonesonde data are obtained from various networks with availability for the year 2010. A total of 10 sites across North America are selected for seasonal and annual analyses (Fig. 1a) and five additional sites located in the western United States (Fig. 1b) are selected for studies of stratosphere-troposphere exchange (note that the Trinidad Head, TH, site was selected for both types of analyses and is shown in both Fig. 1a and b). Information on data networks and station characteristics, including the number of launches available for analysis, are summarized in Table 2. The modeled and observed ozone fields were interpolated at the following 18 standard vertical heights above ground level $(\mathrm{m})$ :
$0,100,250,500,750,1000,1500,2000,3000,4000,5000$, $6000,7500,8500,10000,12000,15000$ and 18000 . The 10 sites depicted in Fig. 1a had launches throughout the entire year and are used to construct seasonal average profiles by averaging over all available launches in a given season at each vertical height. Seasonal averages are chosen to evaluate how models capture transport and photochemistry processes that influence ozone formation (Winter: DJF; Spring: MAM; Summer: JJA; Fall: SON). The modeled ozone mixing ratios are sampled in accordance to available ozonesondes; thus, the variability of the vertical ozone profiles might be underrepresented since the ozonesondes are not continuous throughout each month (Lin et al., 2015). The evaluation of ozone vertical profiles is performed for layers up to 
$8.5 \mathrm{~km}$ since there is less confidence on the tropopause placement for the regional models which was evident by large errors in ozone mixing ratios above $8.5 \mathrm{~km}$ (not shown). The study by Makar et al. (2010) has shown that, when models predict a tropopause height above the one implicit in the ozone background conditions (ozone climatology), then higher ozone mixing ratios will become available in the upper troposphere (UT), resulting in high model errors. In addition to the ozonesonde data, wind speed and temperature profiles are used for stations that included such data in their repositories (wind and temperature profiles are included in the Supplement).

IONS experiments are aimed at measuring tropospheric ozone variability across North America (Thompson et al., 2007). During the IONS-2010 experiment, ozonesondes were launched almost daily between 10 May and 19 June 2010. Its main goal was to determine the latitudinal variability of baseline ozone along the California coast from the surface to the tropopause (Cooper et al., 2011). A total of 230 ozonesondes were launched at seven sites, one in southern British Columbia (Kelowna) and six in California. Figure $1 \mathrm{~b}$ shows the locations of the six IONS ozonesonde sites in California. All IONS sites are located in very rural areas far from fresh emissions. Four of the sites are right on the coast, almost in the water (TH, RY, PS, SN), and in the lowest few hundred meters of the atmosphere they represent depleted ozone from the marine boundary layer, while the other two are inland (Shasta, SH; and Joshua Tree, JT).

The statistical metrics used in the model evaluation and model inter-comparison are root mean square error (RMSE); Pearson correlation coefficient $(R)$; $95 \%$ bootstrapping confidence intervals (indicates significance in differences between models and observations, Efron, 1987); and the fractional difference indicator (FD) used in the stratospheric intrusion case study only, defined as follows:

$\mathrm{FD}(\%)=200(\bmod -\mathrm{obs}) /(\bmod +\mathrm{obs})$,

where "mod" and "obs" denote the modeled and observed ozone values. If all modeled values lie within a factor of 2 of the observations then FD is between $-66.7 \%$ and $+66.7 \%$, and if all modeled values lie within a factor of 3 of the observations then FD is between $-100 \%$ and $+100 \%$. The interpretation of the results is made with caution due to the incommensurability of the comparison of point measurements with grid cell model values.

\section{Evaluation and model inter-comparison of ozone seasonal profiles for 2010}

The ozone vertical profiles for each season and station (Figs. 2-4 and box plots in Figs. S1 and S2 in the Supplement) highlight the variability of model behavior depending on the specific model configuration as well as the impact of seasonal cycles that alter emissions, transport and transfor- mation of ozone. During winter, all models underestimate the mean and variability of ozone mixing ratios in the $1.5-5 \mathrm{~km}$ vertical levels for all stations, with the exception of Boulder, Narragansett and Huntsville. In most cases, the $95 \%$ bootstrapping confidence intervals do not overlap between models and observations in the 1.5 to $5 \mathrm{~km}$ height range, indicating that the differences in the mean are statistically significant. Model behavior near the surface $(0-1 \mathrm{~km})$ varies, with the majority of the models agreeing with observations. There is a notable tendency for most models to underestimate the $0-1 \mathrm{~km}$ mean ozone mixing ratios for the two easternmost sites (Yarmouth and Narragansett; Fig. 3). The ozone mixing ratios exhibit larger variability in the upper layers $(5-8.5 \mathrm{~km})$ with the models behaving differently depending on the site and altitude.

During spring, all models show better performance for the lower layers for most stations. Variable behavior is shown in the two easternmost sites (Yarmouth and Narragansett; Fig. 3). In Yarmouth, the observed ozone is underestimated by all models in the $0.75-6 \mathrm{~km}$ range while the models agree with observations in the lower layers. At Narragansett, a similar underestimation is noted in the $2-6 \mathrm{~km}$ range but the models' behavior varies in the lower layers. The results for Narragansett must be viewed with caution due to the limited number of profiles, which varies from 5 to 8 for each season.

During summer, all models over-predict ozone in the 0$0.5 \mathrm{~km}$ layer at the northern sites of Bratt's Lake and Stony Plain. For the Egbert site, DK1 shows a significant overprediction in the $0-2 \mathrm{~km}$ range. Egbert is located near the Great Lakes (Fig. 1a, STN456) and the complexity of the geography might not be resolved adequately. A similar behavior is noted at Wallops Island where DK1 results stand out from other models in the lowest $0-2 \mathrm{~km}$, possibly resulting from a different representation of the land-water interface and resulting mixing heights. However, as noted below, the summer temperature profiles for DK1 shown in Fig. S2 do not offer conclusive evidence that the ozone differences can be attributed to differences in mixing due to grid spacing, and deposition processes simulated by the model might be another reason for the over-prediction seen in these two sites (deposition could not be evaluated at the time of this study). All models, except DK1, overpredict the mean ozone mixing ratios for Narragansett (eastern part of the domain) at $0-0.25 \mathrm{~km}$ and the same behavior is seen in Yarmouth. At the westernmost site, Trinidad Head, all models overpredict ozone in the $0-1 \mathrm{~km}$ range. Finally, the mean ozone profiles during fall are generally well represented by all models, with some variations depending on the site and height, which cannot be generalized. One common pattern for the eastern and northern sites is the under-prediction of ozone in the 3$6 \mathrm{~km}$ range (the exception is Wallops Island; SON profiles are shown in the Supplement, Fig. S2).

By evaluating the error in the seasonal ozone vertical profiles for two height ranges (lower troposphere, LT, 0-2 km; and upper troposphere, UT, $2-8.5 \mathrm{~km}$ ), we observe the ex- 
(a)
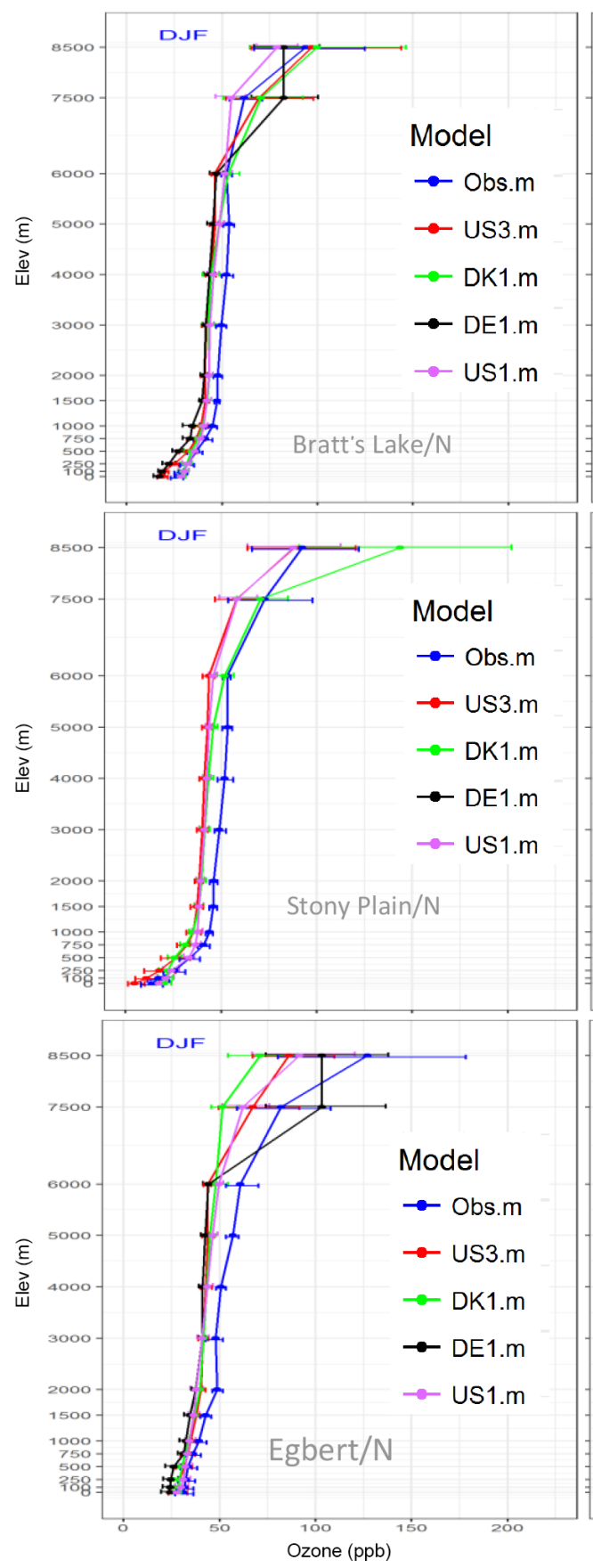

(b)

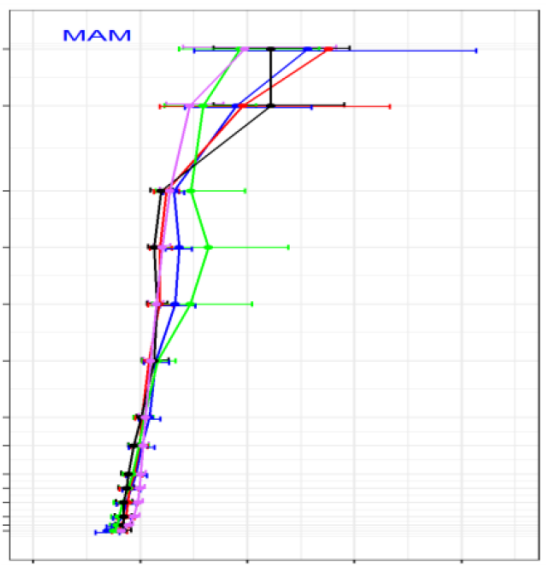

MAM

MAM
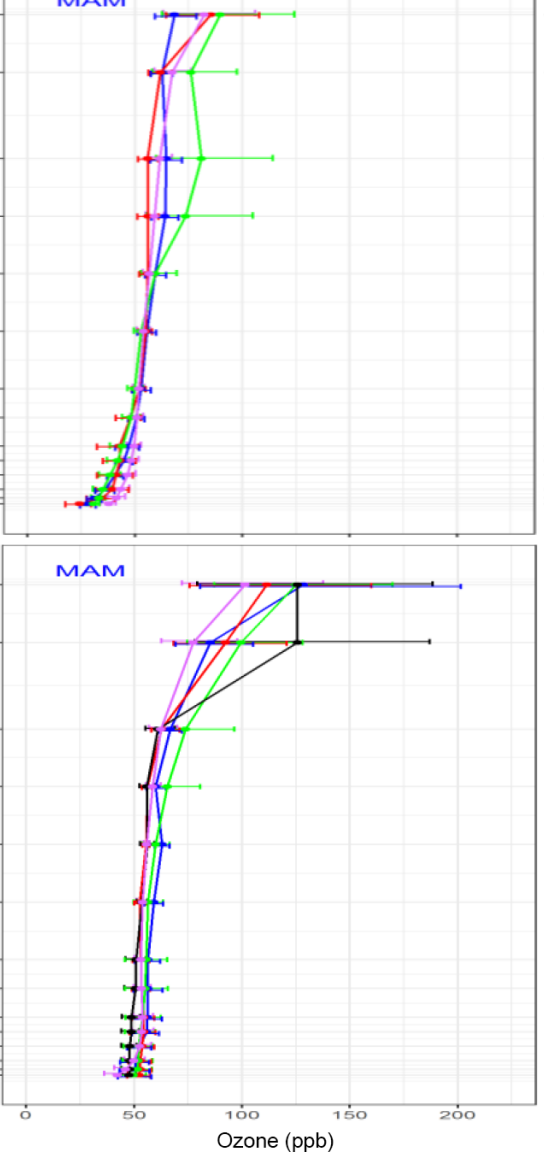

(c)
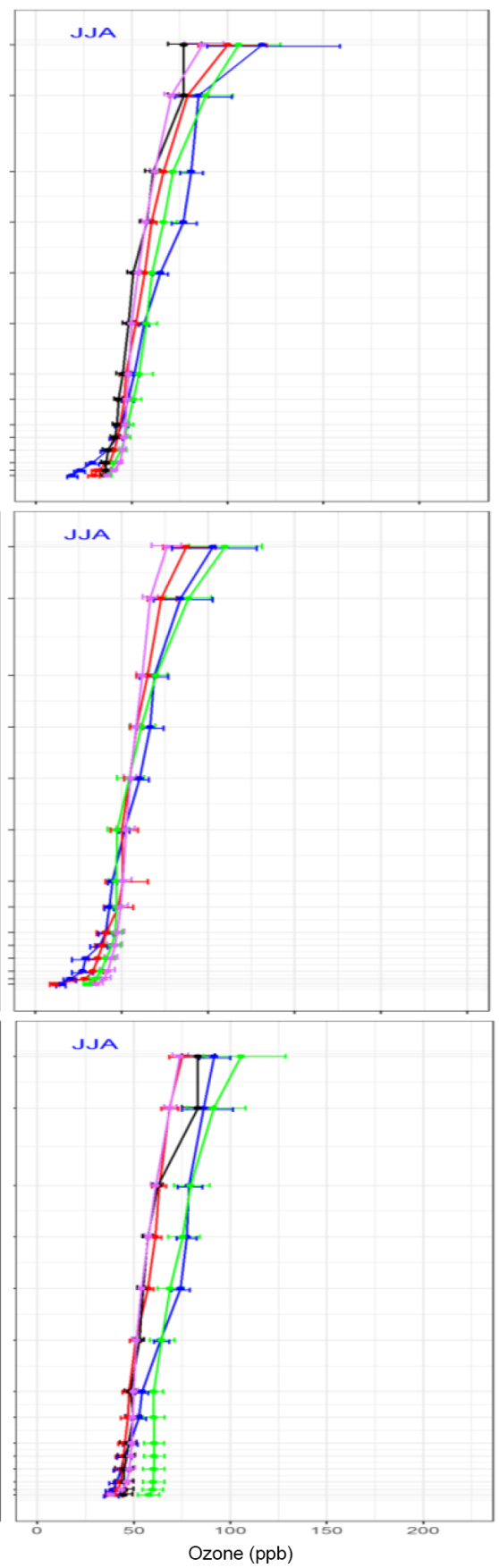

Figure 2. Seasonal vertical profiles of ozone mixing ratios for 2010 (a: winter; b: spring; $\mathbf{c}$ : summer), for stations located in the northern part of the domain. The horizontal lines indicate the $95 \%$ bootstrapped confidence interval for each vertical layer. Note that Stony Plain does not include model outputs from DE1 as the model domain does not cover that station.

pected error magnitude difference between LT and UT given the increase in the ozone mixing ratios in the upper layers (Fig. 5). For this analysis, the RMSE is calculated at each of the standard altitude levels listed in Sect. 2.2 using all available launches in a given season and then averaged across all standard levels in the LT and UT ranges. The LT errors are $2-4 \mathrm{ppb}$ higher for the summer compared to other seasons for most models (the average RMSE for all stations and models during summer is 12 and $10 \mathrm{ppb}$ for the fall). The lowest LT errors are seen in winter and spring with an av- 
(a)
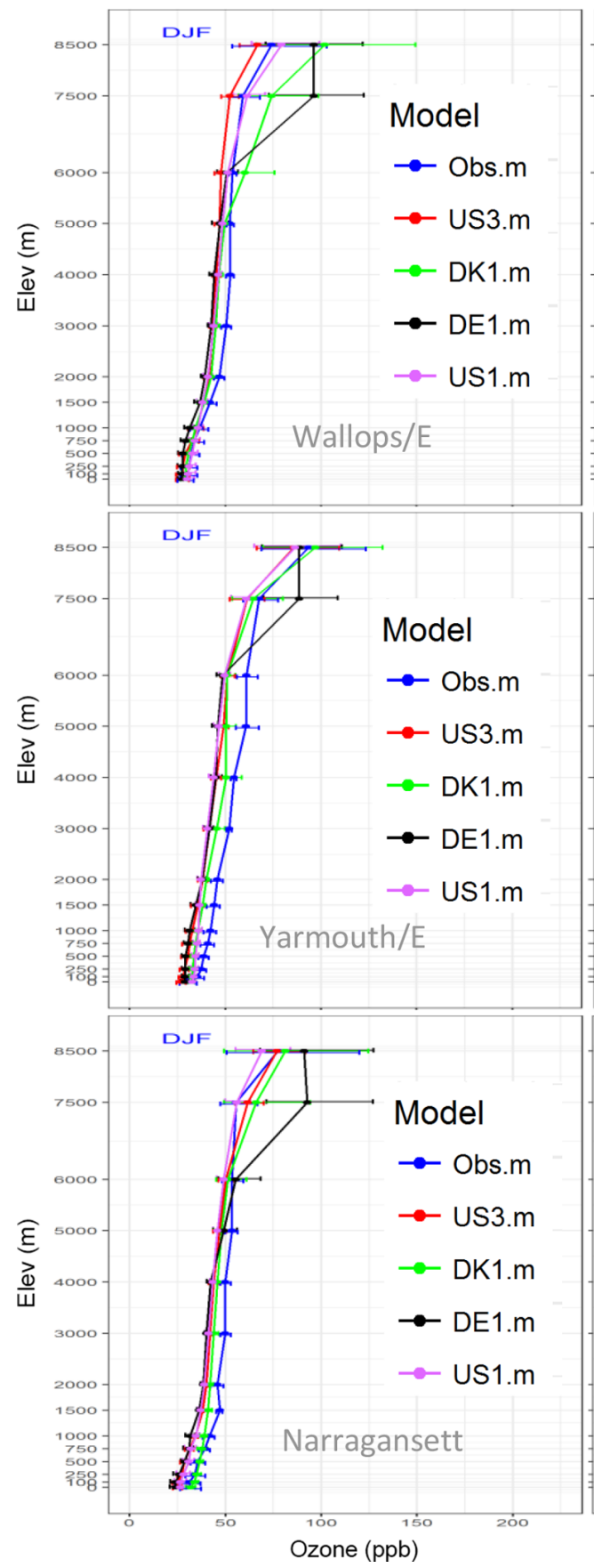

(b)
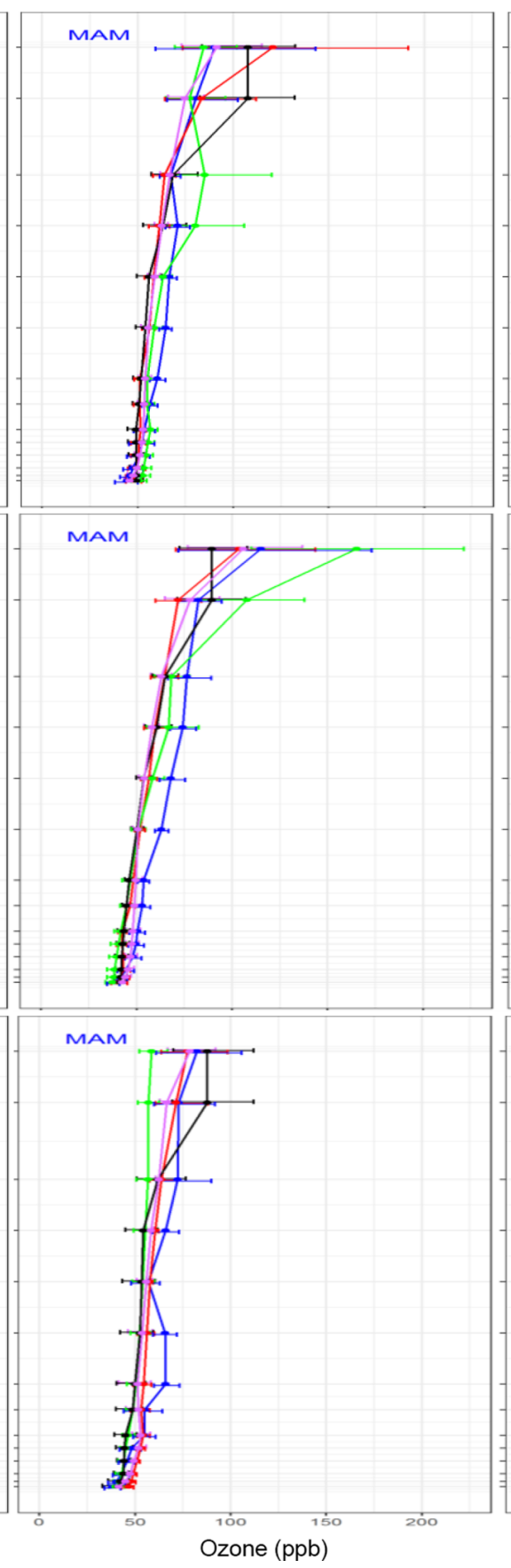

(c)
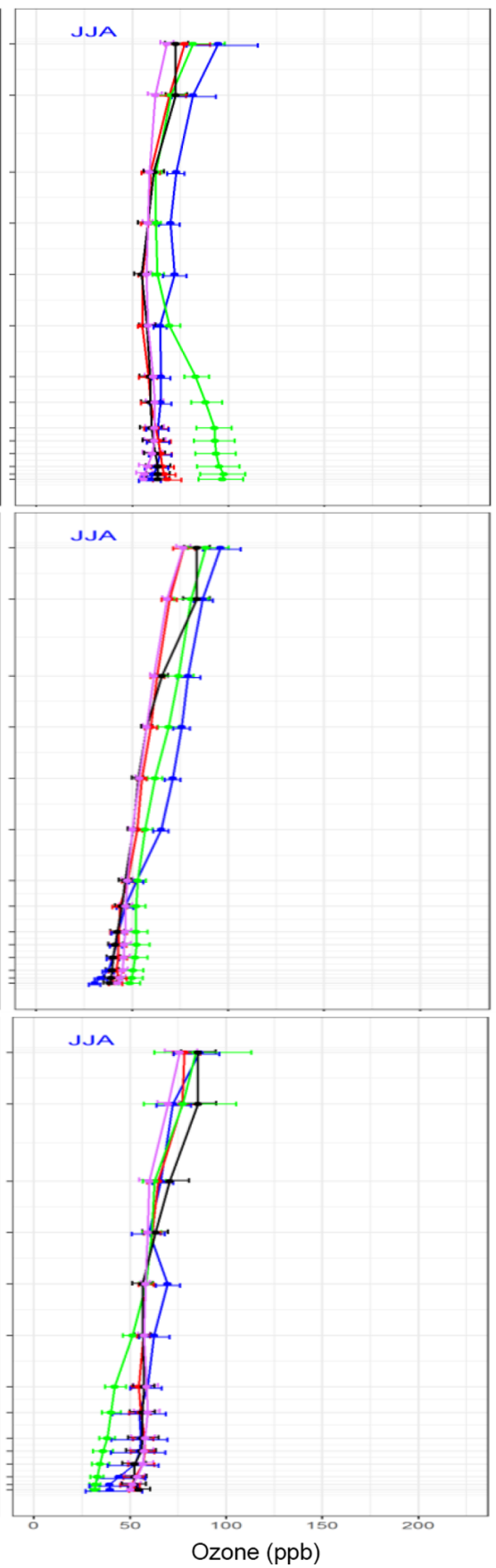

Figure 3. Seasonal vertical profiles of ozone mixing ratios for 2010 (a: winter; b: spring; c: summer), for stations located in the eastern part of the domain. The horizontal lines indicate the $95 \%$ bootstrapped confidence interval for each vertical layer. Note that Narragansett has limited amount of ozonesondes for all seasons (less than 10 for each season) and the results should be viewed with caution.

erage error of $\sim 8 \mathrm{ppb}$ across all models and sites. At most sites, the DK1 simulations for LT exhibit a higher RMSE than other models during summer and fall with RMSE values that range from 6 to $32 \mathrm{ppb}$ (32 ppb RMSE for the Wallops Island site and $24 \mathrm{ppb}$ for Huntsville in the fall are the maxi- mum values). Vertical profiles of temperature and wind speed for DK1 do not show large variations for Wallops Island during summer (Figs. S3, S4), but for Huntsville the temperature profile is underestimated consistently for all seasons and layers (Fig. S3). Wind speed profiles were not available 
(a)
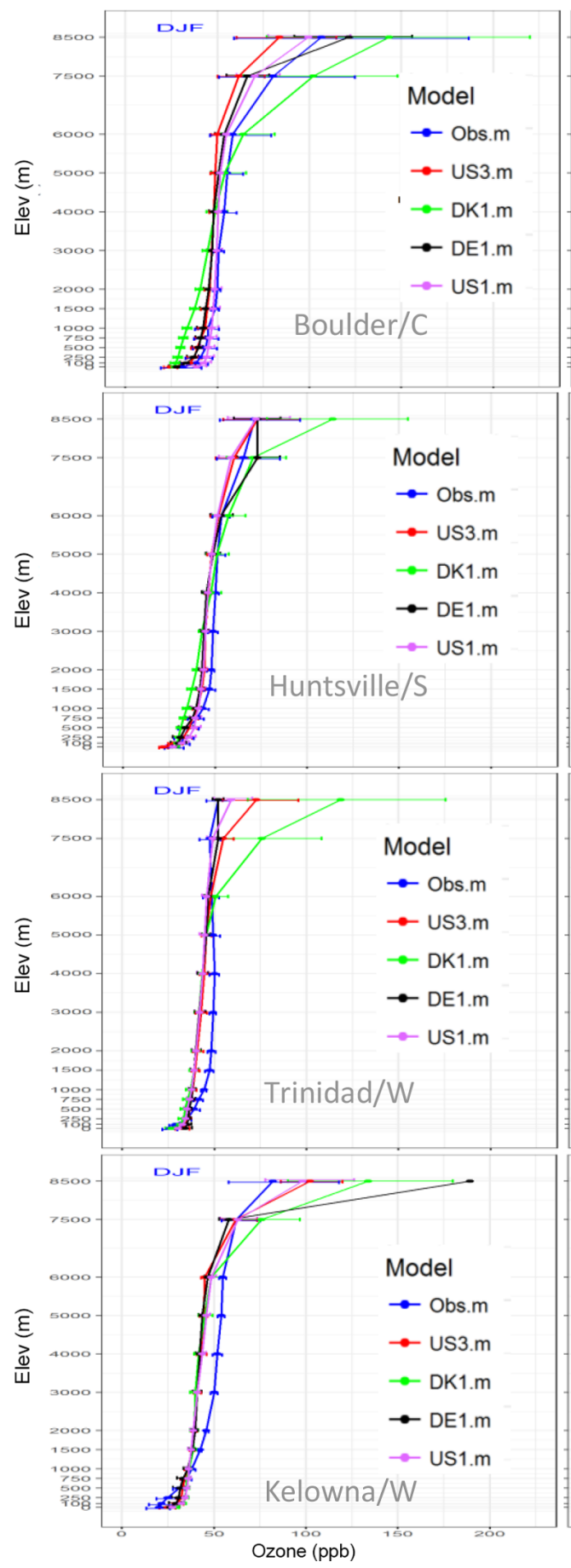

(b)
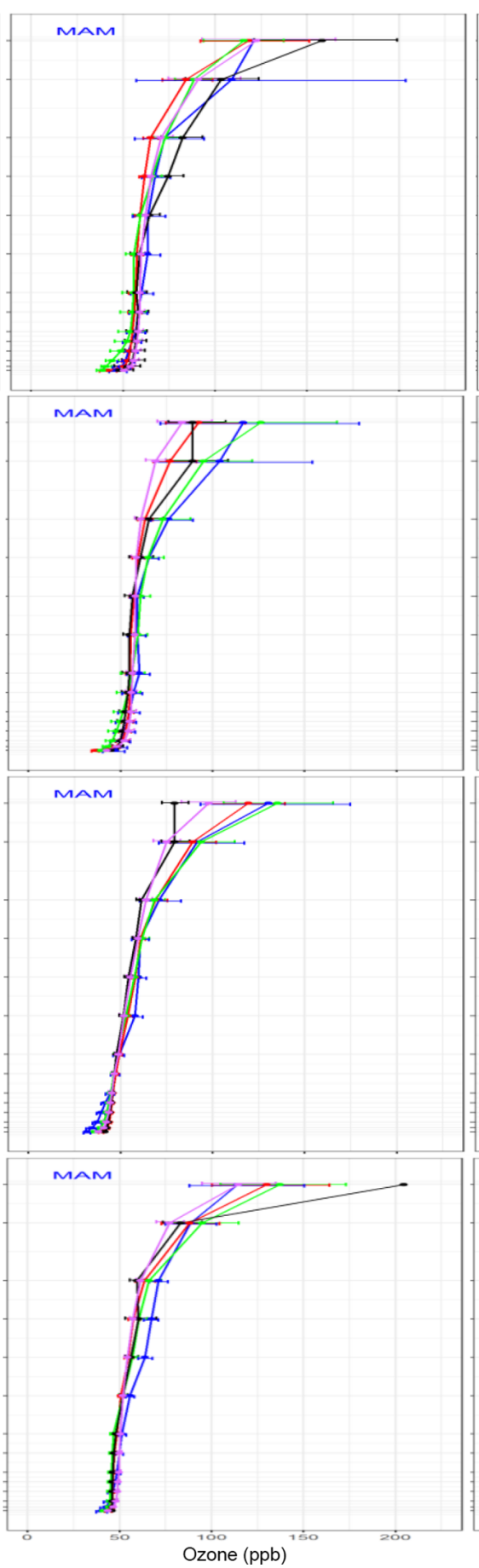

(c)
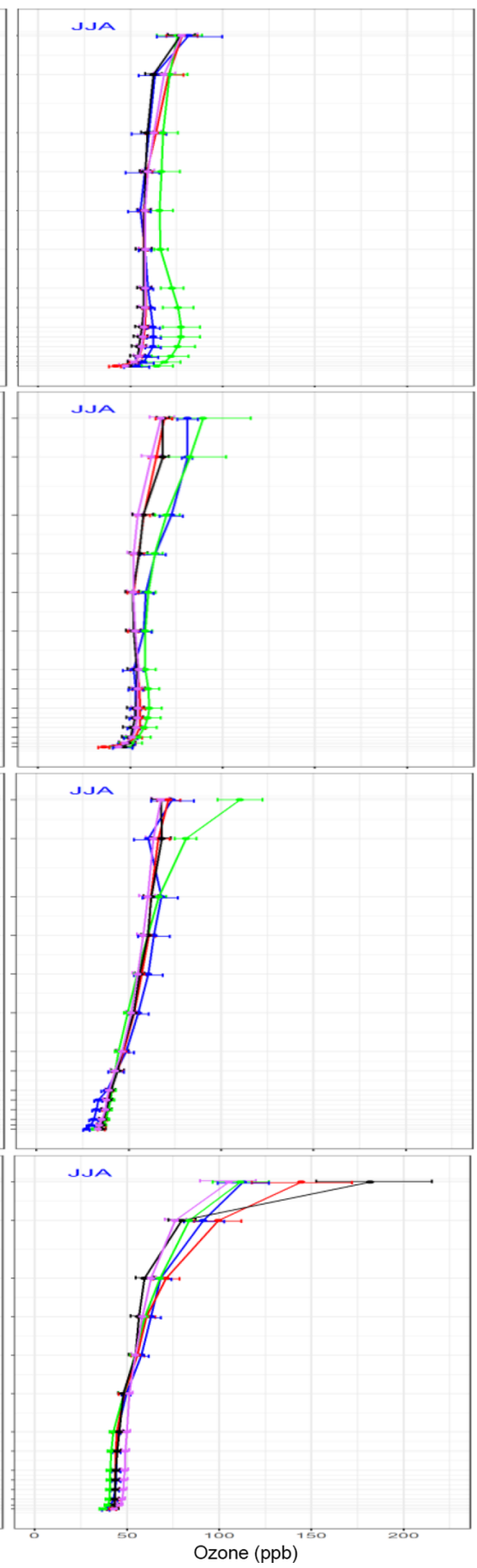

Figure 4. Seasonal vertical profiles of ozone mixing ratios for 2010 (a: winter; b: spring; $\mathbf{c}$ : summer), for stations located in the central (C), south (S) and west (W) part of the domain. Horizontal lines indicate the $95 \%$ bootstrapped confidence interval for each vertical layer.

for Huntsville to further examine the large RMSE values for DK1.

There is a peak in the LT and UT RMSE at Yarmouth during fall associated with all modeling systems. Since this is the easternmost site in the model domain, it might indicate that the eastern boundary condition is not appropriate for the fall or the weather variables exhibit errors that influence ozone mixing ratios. The temperature profiles are very similar be- 

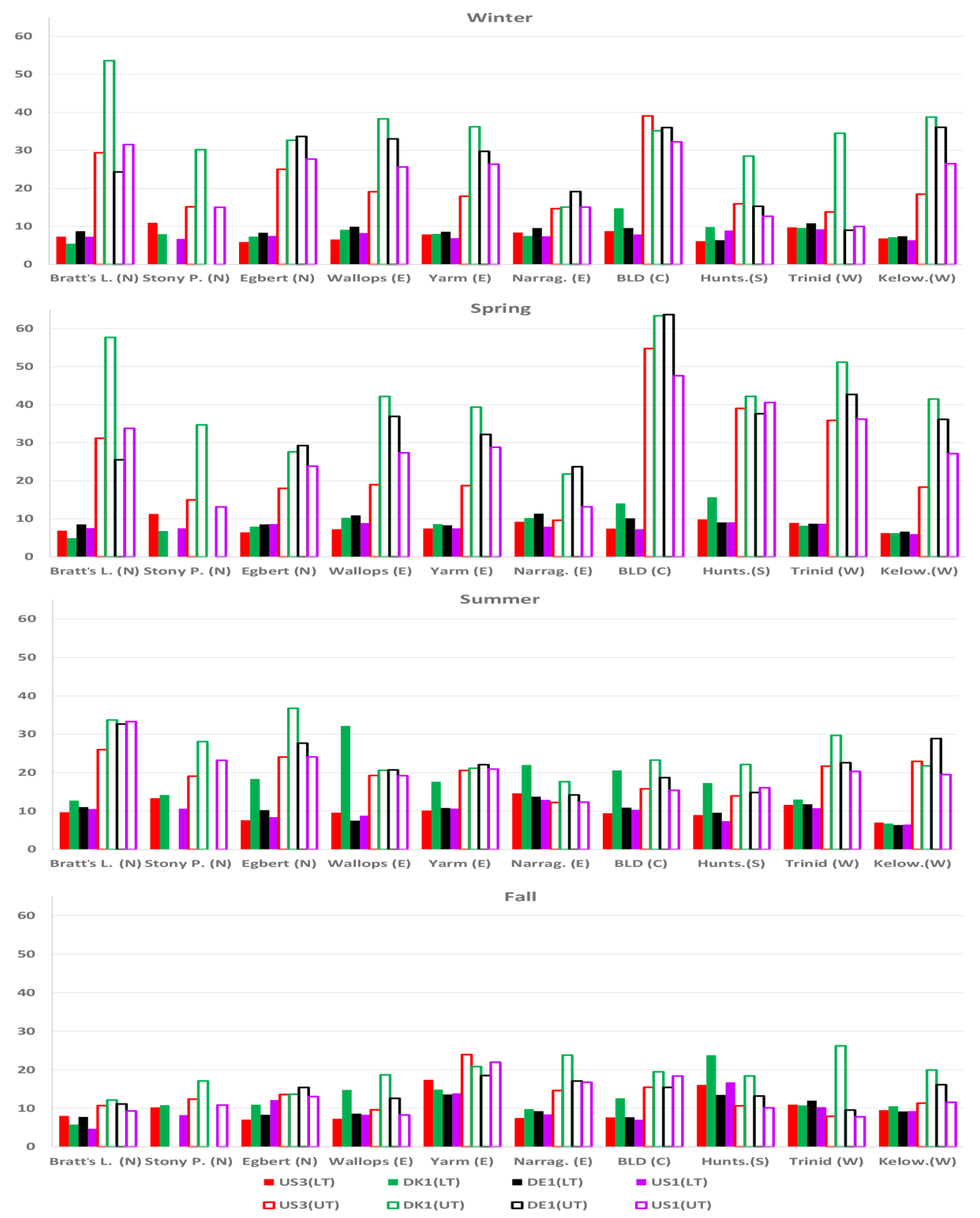

Figure 5. Seasonal average RMSE of ozone mixing ratio (ppbv) for each station and model, calculated for two height ranges: LT (lower troposphere $=0-2 \mathrm{~km}$ ) and UT (upper troposphere $=2-8.5 \mathrm{~km}$ ).

tween all models and observations for Yarmouth (Fig. S3), but the LT wind speed is underestimated by DE1 and US1 (Fig. S4). The wind and temperature profiles for US3 in Yarmouth in the fall do not show any significant variation from the observations to explain the higher RMSE value. In general, the average RMSE over all stations for the LT increases for all models in the following order: winter, spring, fall, summer. All models have similar error magnitudes for the LT, with DK1 being an outlier during summer and spring when it has noticeably higher RMSE values than the other 
models. The seasonal change in the variance of simulated and observed LT ozone mixing ratios is the same as the change seen in the RMSE values (higher during summer and fall and lower during spring and winter). All models are less variable than the observations with the exception of DK1 for summer and fall.

For the UT, the highest errors in ozone mixing ratio occur during winter and spring. The average RMSE across all stations and models during spring is $33 \mathrm{ppb}$ : $26 \mathrm{ppb}$ for winter, $22 \mathrm{ppb}$ for summer and $15 \mathrm{ppb}$ for fall. There is a tendency for all models to produce high UT errors for the Boulder site during winter and spring and for Huntsville and Trinidad Head for spring. For Trinidad Head and Huntsville, only DK1 underestimates the observed temperature for all vertical levels and seasons, whereas it overestimates the UT temperature profiles for Boulder (Fig. S3). These results do not provide any insights into the cause of the common high UT errors across all models but given that they occur in all models despite different meteorological drivers and model configurations they do suggest that the lateral boundary conditions are a major factor. In general, the average UT RMSE over all stations increases for all models in the following order: fall, summer, winter, spring. The higher UT errors agree with the vertical profile analysis discussed previously, where large deviations from the observed ozone profiles are seen at the $1-6 \mathrm{~km}$ vertical range. The seasonal change in the variance of simulated and observed UT ozone mixing ratios is the same as the change seen in the RMSE values (higher during spring and winter and lower during summer and fall). All models are less variable than observations with the exception of DK1 for winter and summer.

The statistical evaluation and inter-comparison of modeled ozone profiles for the lower $(0-2 \mathrm{~km})$ and upper troposphere $(2-8.5 \mathrm{~km})$ are further explored with the Taylor diagrams in Fig. 6 for each season and vertical range. For these Taylor diagrams, observations and model results for each standard vertical level were averaged over all vertical levels in a given vertical range (LT or UT) for each launch and the resulting vertical averages for each launch were then used to compute the metrics depicted in the diagrams. Thus, the variability metrics (correlation coefficient and normalized standard deviation) measure the temporal variability across launches in a given season at a given station. The seasonal LT Taylor charts highlight the variability in model performance during all seasons. One common feature throughout all seasons is that most models underestimate the observed variability at most sites as indicated by standard deviation ratios (measured by concentric circles around the origin) of less than 1 . During winter (Fig. 6, DJF_LT) very low (and negative) correlations and high centered RMS differences are evident for the western sites of Trinidad Head and Kelowna (all models) in the LT. The predictions are improved for Egbert, where all models have correlations above 0.85 and low RMSE. In general, LT variations at both sites in the western part of the domain are not captured well by the four modeling systems during all seasons.

Spatial variability in LT model performance is still evident in the statistical metrics for spring (Fig. 6, MAM_LT). LT correlations are somewhat improved for the summer (with 13 points showing correlations above 0.6 ) and further improved in the fall (with most of the points having correlations above 0.6). It is apparent that no single model outperforms the others in the station-by-station comparison. When considering the overall statistics for all stations (Fig. S5), US3, US1 and DE1 share similar performance for spring, summer and fall. It is interesting to also note the differences and commonalities between the models: US3 and US1 share common meteorological inputs, while US3 and DE1 are based on the same air quality model (though a different model version). There is no obvious attribution of the model performance to these differences and commonalities when looking at each individual station.

As discussed earlier, the UT ozone mixing ratios are more challenging for all four modeling systems and this is evident by looking at the station-based Taylor diagrams (Fig. 6, UT) as well as the station-averaged diagrams in the Supplement (Fig. S5). As was the case for the LT, the modeled temporal variability tends to be lower than the observed temporal variability across all models and sites. Models US1 and US3 have very similar performance at most stations. During summer and fall, there is less spread in the model results, with US3, US1 and DE1 performing similarly for most stations and DK1 having the most distinct behavior compared to the other three models. For example, DK1 at Wallops Island during summer and fall has high RMSE values (shown in Fig. 5) and we can see from Fig. 6 (JJA_UT and SON_UT, red triangle) that the correlation is low and RMSE is high.

The variability of model performance and the lower correlations during winter, spring and summer are further explored by analyzing the average profiles. The average of winter ozone profiles over all stations (Fig. 7a) shows underprediction in the $1-6 \mathrm{~km}$ height range. This common condition is also seen for the western, northern and eastern sites separately (Fig. 7b-d). For the eastern sites, ozone is underpredicted from the surface to $6 \mathrm{~km}$, while for the western sites all models indicate over-prediction of ozone in the levels below $250 \mathrm{~m}$. A similar pattern is seen during spring for the 1$6 \mathrm{~km}$ height range but less pronounced compared to winter. During the summer period all models underestimate ozone in the lower vertical range $(0-1 \mathrm{~km})$ with biases that range from 1 to $12 \mathrm{ppb}$. This explains some of the high errors seen in the LT for the summer (seen in Fig. 5). To gain insight into how lateral boundary conditions might have influenced the performance of three of the modeling systems (DE1, US3, and DK1), the chemically inert tracer results are discussed in the following section for all seasons and sites. 

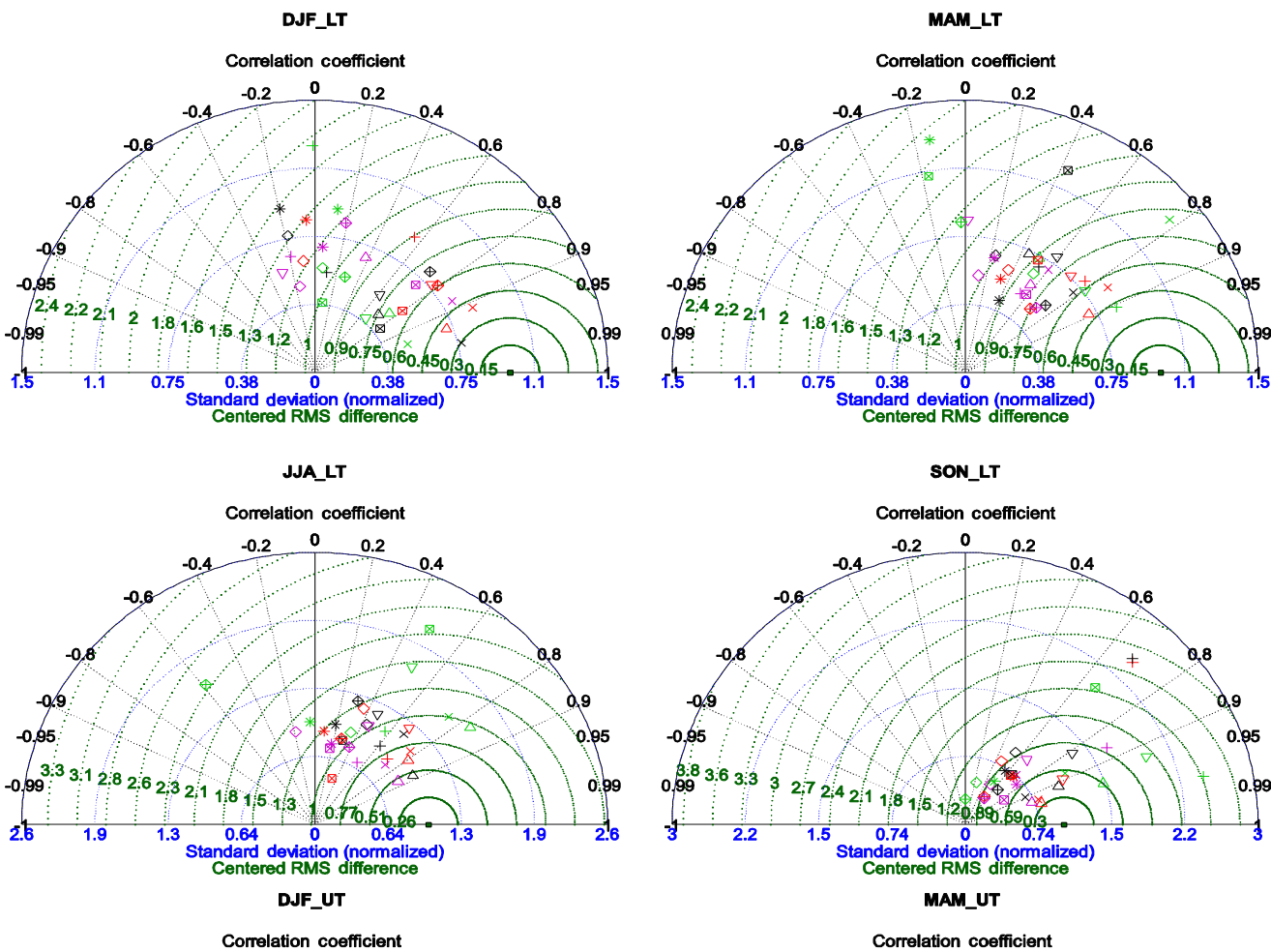

$\triangle$ Wallops

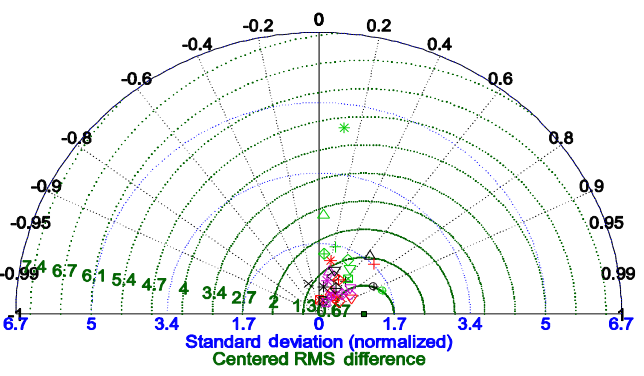

MAM_UT

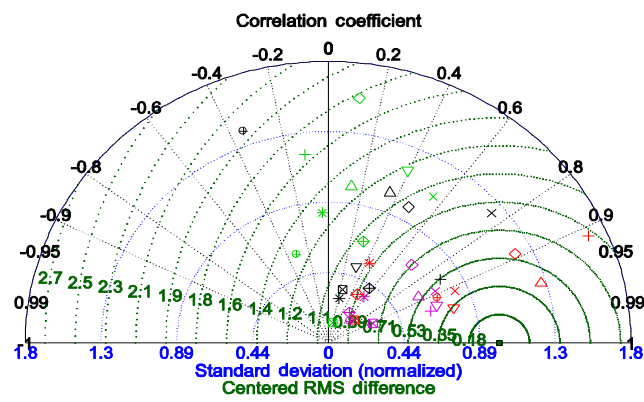

+ Bratt's Lake

$\times$ Egbert

Kelowna

$\nabla$ Yarmouth

凶 Boulder
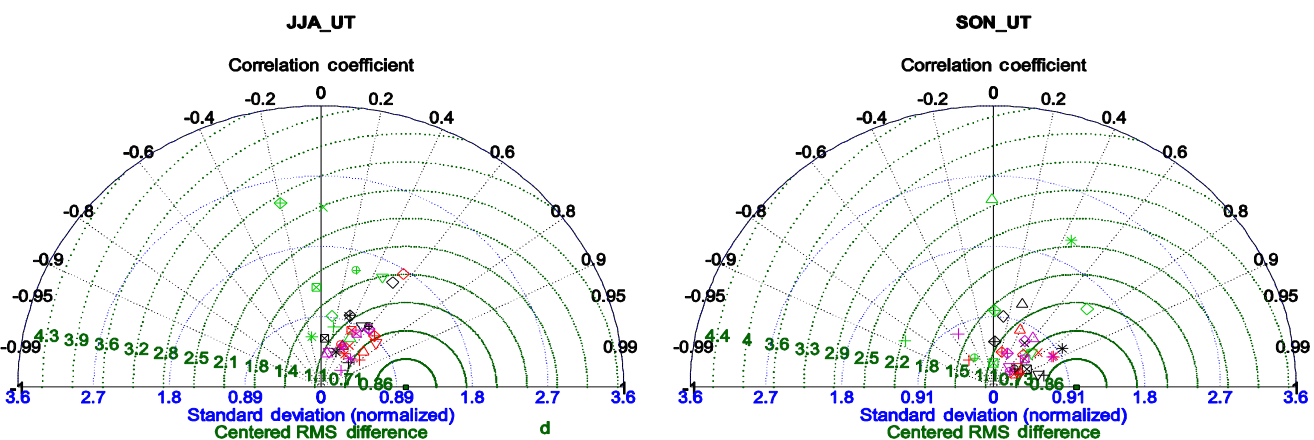

US3

DK1

DE1

US1

Figure 6. Seasonal Taylor diagrams using normalized standard deviations for two height ranges: LT (lower troposphere $=0-2 \mathrm{~km})$ and UT (upper troposphere $=2-8.5 \mathrm{~km}$ ). Stony Plain (STN021) is excluded because DE1's domain does not incorporate the site's location.

\section{Influence of lateral boundary conditions to ozone profiles using chemically inert tracers}

Three chemically inert tracers are included with the simulations by all modeling groups but only three of the modeling systems provided 3-D data of the tracer mixing ra- tios (Table 1). We are interested in the relative contribution of each lateral boundary tracer to the total tracer mixing ratios and the characteristics of each tracer's vertical profile at the 10 ozonesonde sites. The relative contribution of each tracer (BC1, BC2 and $\mathrm{BC} 3)$ is assessed by normalizing 
(a) Winter (10)

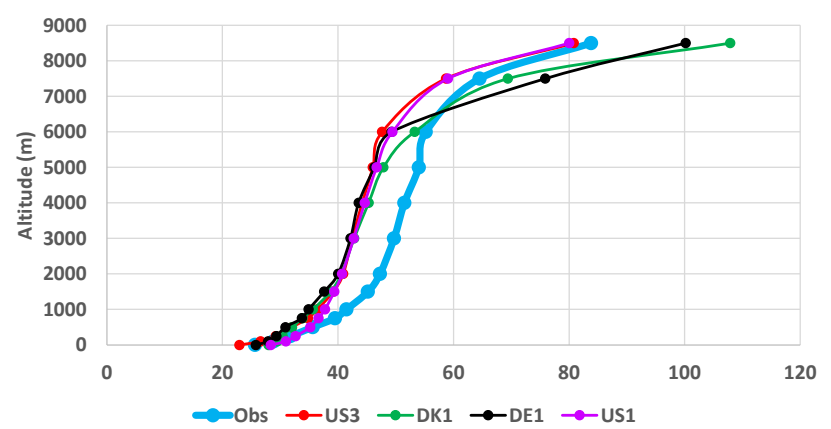

(c) Winter - western sites (2)

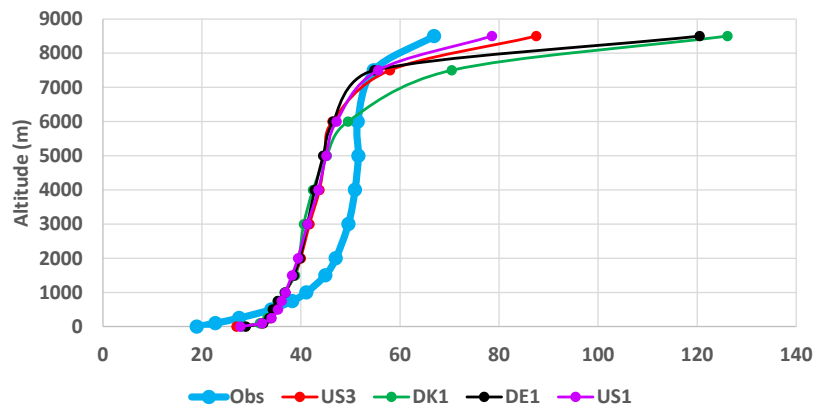

(e) Spring (10)

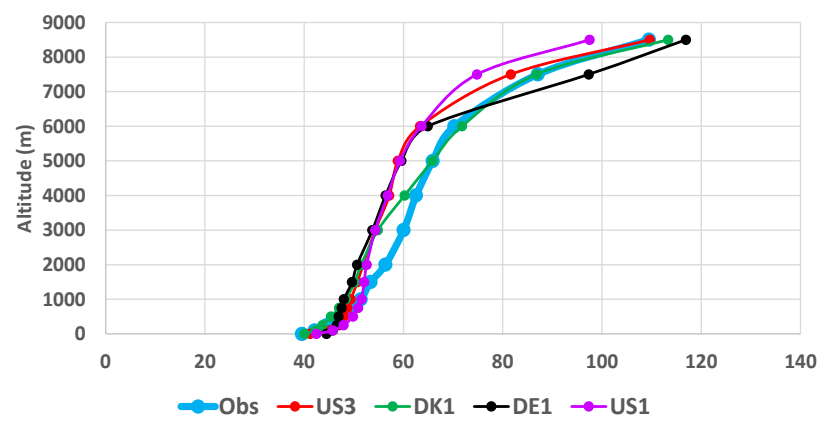

(b) Winter - northern sites (3)

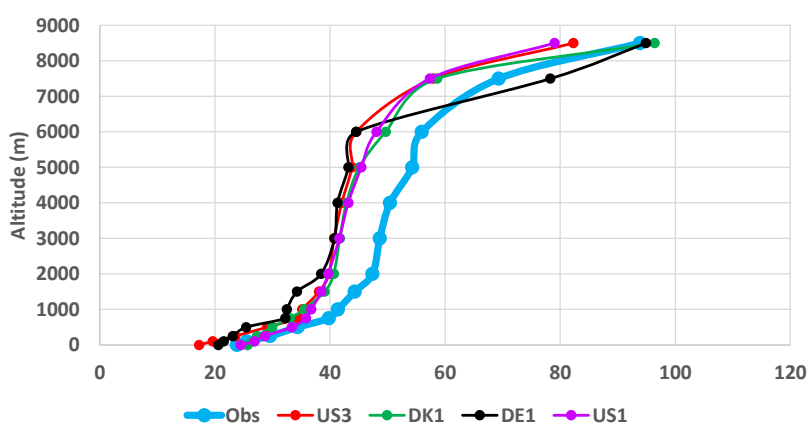

(d) Winter - eastern sites (3)

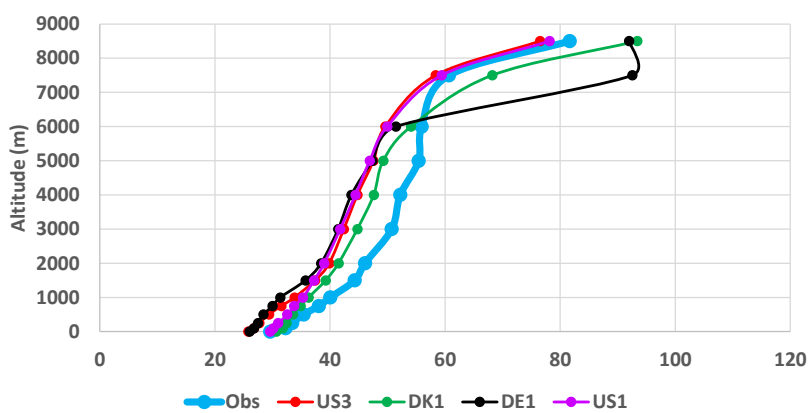

(f) Summer (10)

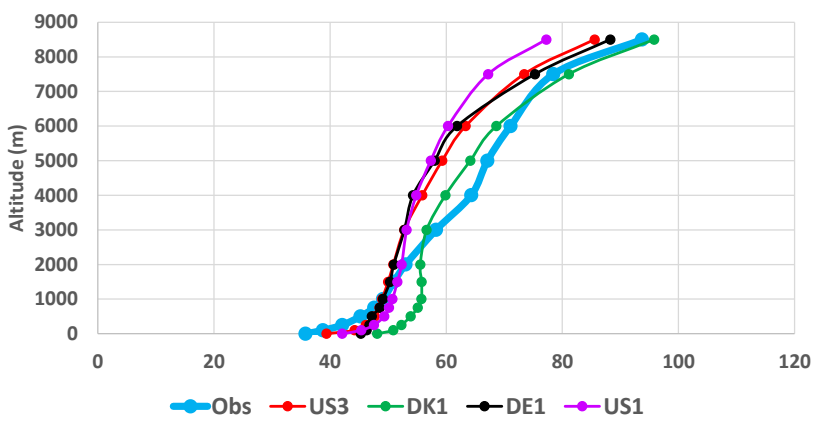

Figure 7. Average ozone profiles for winter (DJF): (a) all stations, (b) northern sites, (c) western sites, (d) eastern sites for spring (all stations) and summer (all stations). The number of sites is shown in parentheses next to the panel title.

each one with the sum of all tracer mixing ratios $(\mathrm{BCtot}=$ $\mathrm{BC} 1+\mathrm{BC} 2+\mathrm{BC} 3)$. This normalization allows us to compare contributions from each tracer at each site and season (Fig. 8). The normalized values are assessed for three vertical layers: LT represents the lower troposphere $(0-2 \mathrm{~km})$, MT the middle troposphere $(2-8.5 \mathrm{~km})$ and UTLS the upper troposphere to lower stratosphere $(8.5-18 \mathrm{~km})$ following Nopmongcol et al. (2017). BCtot is calculated for each vertical layer separately. More specifically, the percentage contribution from each tracer $\mathrm{BC} 1, \mathrm{BC} 2$ and $\mathrm{BC} 3$ to the $\mathrm{LT}, \mathrm{MT}$ and UTLS for each model, station and season is analyzed and discussed.

The lower-troposphere mixing ratios (LT) are influenced by both $\mathrm{BC} 1$ (lateral boundary set to nonzero below $750 \mathrm{hPa}$ ) and $\mathrm{BC} 2$ (lateral boundary set to nonzero between 750 and $250 \mathrm{hPa}$ ). The relative contributions of $\mathrm{BC} 1$ and $\mathrm{BC} 2$ depend on season and station location. For example, during summer, $\mathrm{BC} 2$ contribution is stronger for all sites (50\%-85\%) except Trinidad Head, where $\mathrm{BC} 1$ and $\mathrm{BC} 2$ have an almost equal contribution. This indicates the importance of lateral boundary conditions up to $250 \mathrm{hPa}$ for the lower-troposphere ozone mixing ratios $(0-2 \mathrm{~km})$. Looking back at the poor model performance for the western sites of Trinidad Head and Kelowna for winter and summer (Fig. 6; DJF_LT and JJA_LT), one possible explanation and point of further investigation would be the influence of lateral boundary conditions up to $10 \mathrm{~km}$ (250 hPa). 
(a)

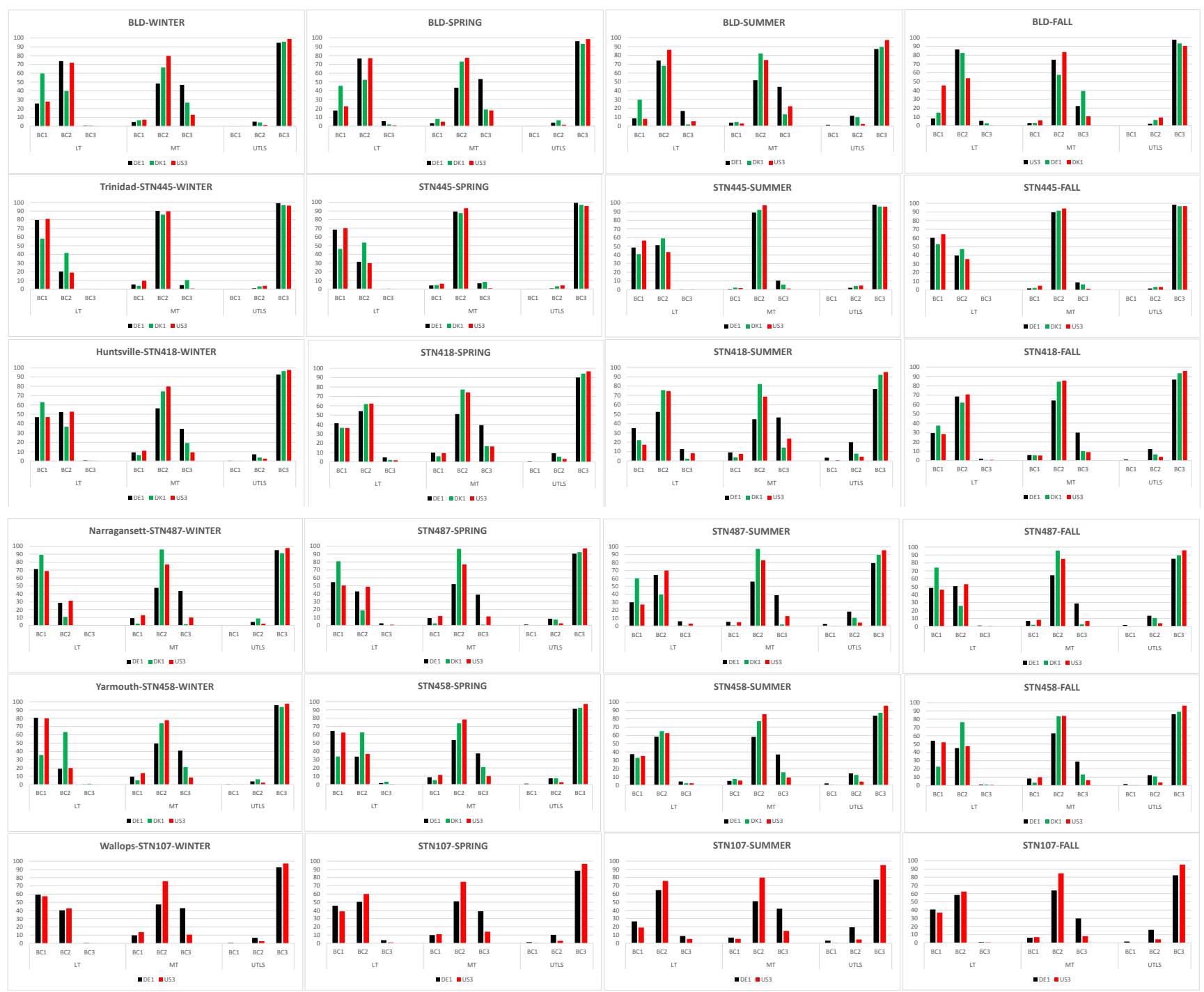

Figure 8.

The MT tracer mixing ratios are primarily influenced by the $\mathrm{BC} 2$ tracer with some contribution from $\mathrm{BC} 3$. The $\mathrm{BC} 3$ contribution to MT is more pronounced for the DE1 model for all seasons and sites. The US3 model shows a small contribution to MT from $\mathrm{BC} 1$ and $\mathrm{BC} 3$, except for Boulder and Huntsville. This means that the lateral boundary conditions within the vertical range $750-250 \mathrm{hPa}$ primarily influence the ozone mixing ratios in the MT. The UTLS mixing ratio is almost exclusively influenced by the $\mathrm{BC} 3$ tracer for all seasons, models and sites.

Since chemistry is not part of the BC experiments, the relative contributions analyzed here are primarily proxies for the transport and deposition mechanisms. The seasonality of contributions seen in the LT and MT layers is, thus, directly related to planetary boundary layer processes and designates the significance of the influence that lateral boundary conditions have during each season. An in-depth multi-model comparison of the inert tracer mixing ratios at the surface is provided by Liu et al. (2018).

\section{Case study: stratospheric intrusions during May-June 2010}

Stratosphere to troposphere transport is an important process that affects tropospheric ozone (Stohl et al., 2003; Akritidis et al., 2016; Langford et al., 2018). This analysis addresses the ability of different air quality modeling systems to represent the relevant dynamical processes during springtime stratospheric intrusions above the western United States, capital- 
(b)

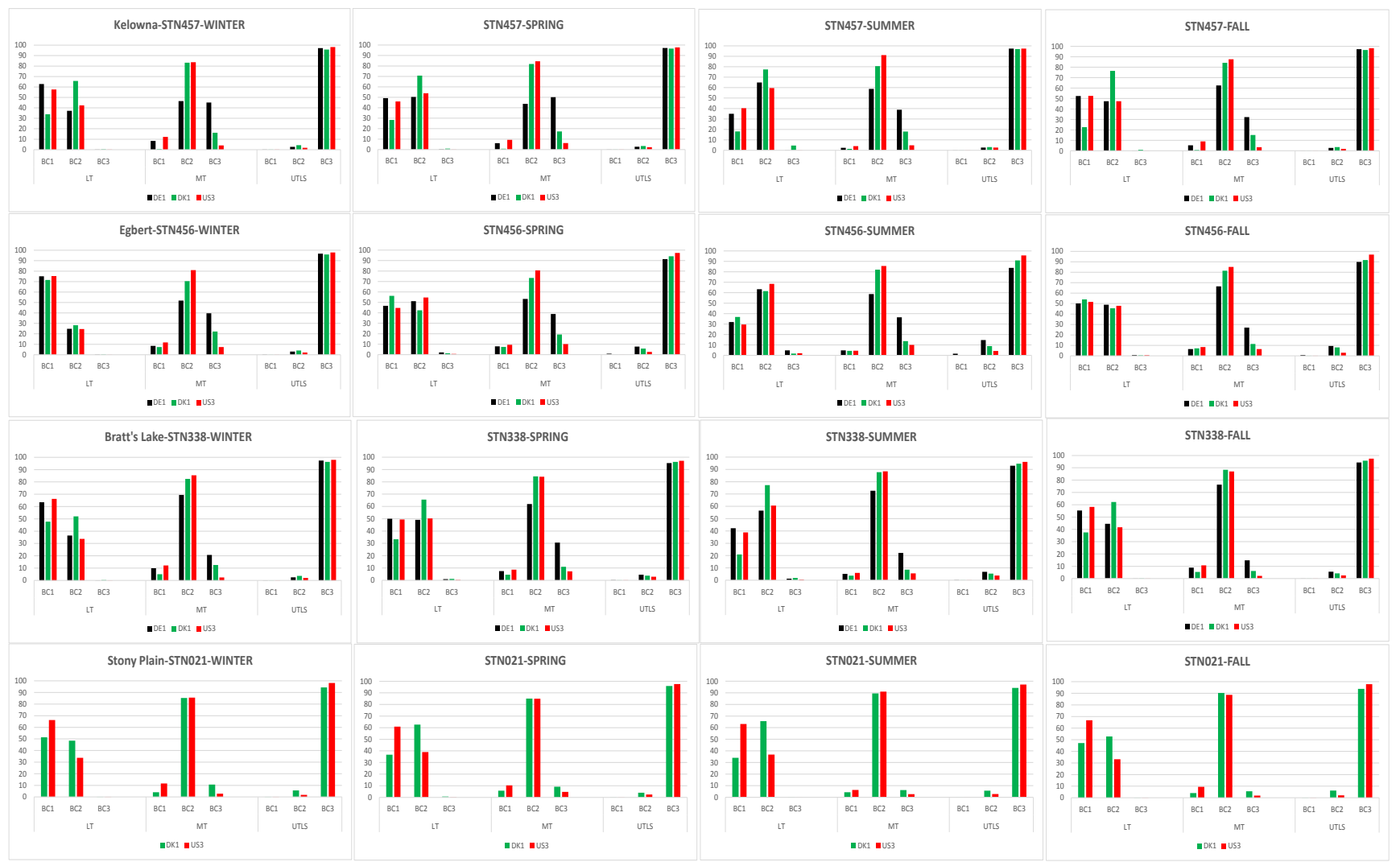

Figure 8. Percentages of lateral boundary contributions (BC1, $\mathrm{BC} 2$ and $\mathrm{BC} 3)$ to the total (BCtot) at each specific height range, ozonesonde site, model and season. LT represents the lower troposphere $(0-2 \mathrm{~km})$, MT the middle troposphere $(2-8.5 \mathrm{~km})$ and UTLS the upper troposphere to lower stratosphere $(8.5-18 \mathrm{~km})$. BC1: lateral boundary conditions nonzero only at the $0-750 \mathrm{mb}$ level; BC2: lateral boundary conditions nonzero only at the $750-250 \mathrm{mb}$ level; BC3: lateral boundary conditions are nonzero only at the levels above $250 \mathrm{mb}$.

izing on the AQMEII3 simulations for 2010 and ozonesondes from the IONS campaign (Cooper et al., 2011, 2012). For average conditions, the upper-tropospheric ozone mixing ratios decrease from north to south for a given altitude (Liu et al., 2013). The IONS measurement data demonstrate a gradient of $\sim 40 \mathrm{ppb}$ at $8 \mathrm{~km}$ a.s.l. between the northernmost and southernmost coastal sites during the study period (Fig. 9a). Factors contributing to the gradient include stronger influence from a lower tropopause and more frequent stratospheric intrusions at higher latitudes, as well as greater influence from low-ozone tropical air masses at lower latitudes (Cooper et al., 2011). Below $4 \mathrm{~km}$ there is little latitudinal difference in the average ozone profiles. Only Joshua Tree (Fig. 1b), downwind of the Los Angeles Basin, exhibits a departure from the mean profile with enhanced mixing ratios (Fig. 9a).

A comparison of the distribution of modeled versus observed ozone profiles (5th, 50th and 95th percentiles using 131 profiles at six IONS sites; Fig. 9b) reveals that the median ozone mixing ratio increases with altitude in the first
$1000 \mathrm{~m}$, as deposition reduces ozone mixing ratios near the ground (e.g., Chevalier et al., 2007). In addition, the coastal sites (four out of six) represent depleted ozone from the marine boundary layer, which can also be seen in the mean ozone profiles for each station in Fig. 9a; the four coastal sites have almost identical ozone mixing ratios between 0 and $250 \mathrm{~m}$. The models might not be able to capture the influence of marine air due to the horizontal grid spacing and how each model treats subgrid-scale processes (i.e., for a grid cell that includes both land and sea surface). The effect of surface processes on ozone is also evident by the strong gradient in the first $2 \mathrm{~km}$ of the troposphere, ranging between 10 and $20 \mathrm{ppb} \mathrm{km}^{-1}$ at all sites. The observed and modeled median profiles are in close agreement mostly above $250 \mathrm{~m}$ (Fig. 9b). All models show a similar general structure, with overestimation of the median in the first kilometer and with few exceptions above $6 \mathrm{~km}$. Another common feature to all models is the smaller range between the 5th and 95th percentiles compared to the observed spread at all levels, with the only exception being DK1 in the first $2 \mathrm{~km}$. The posi- 


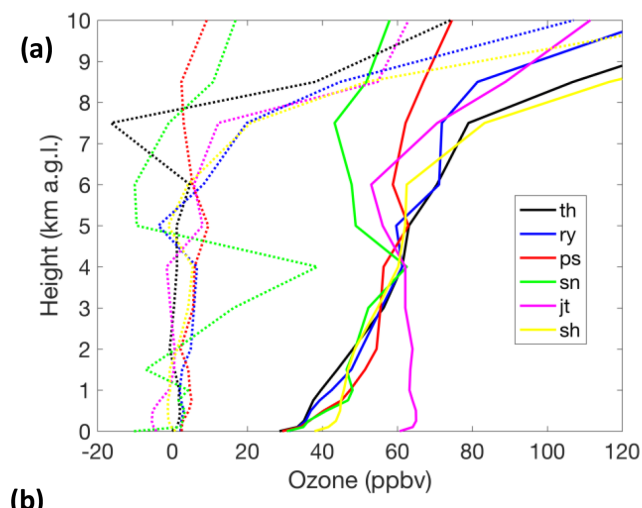

(b)
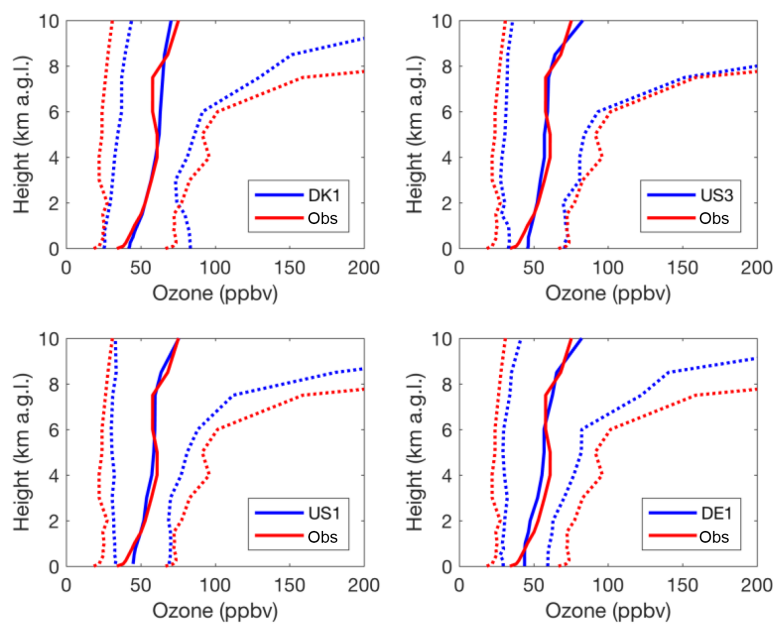

Figure 9. (a) Mean ozone profiles using all available IONS ozonesondes at each site (10 May-20 June 2010) interpolated at specific vertical levels. The dotted lines show the mean difference between the profiles during average and episodic conditions (episodic - average). The episodic periods taken are 22-29 May and 7-14 June. During intrusions, the average $\mathrm{O}_{3}$ enhancement is up to $40 \mathrm{ppb}$ in the first $8 \mathrm{~km}$ from the surface (San Nicolas, SN; green dotted line) and reaches $105 \mathrm{ppb}$ at $10 \mathrm{~km}$ altitude (Point Reyes, RY; blue dotted line). Note that JT and SH are inland sites; all other sites are coastal. (b) Observed (red) and modeled (blue) ozone percentiles (5th, 50th, 95th) during the May-June IONS campaign (131 profiles at six sites). Each panel corresponds to a different modeling system.

tive bias in the PBL during summer at North American stations was also found for the simulations performed as part of AQMEII Phase 1 (e.g., Solazzo et al., 2013), although it should be noted that those simulations were performed with a different suite of models for a different year, were driven by different boundary conditions and were not evaluated at the IONS locations. In the first kilometer, the overestimations are likely due to inaccuracies in PBL processes such as marine air influence, emissions, photochemistry and deposition. Given the proximity of the IONS sites to the regional domain boundaries, the analysis of the inert boundary tracers in Sect. 4, and the comparison of global and regional model simulations at Trinidad Head presented in Hogrefe et al. (2018), the errors above $6 \mathrm{~km}$ are likely caused by errors in the representation of tropopause dynamics in the models that affected the downward mixing of higher stratospheric ozone mixing ratios.

The identification of stratospheric intrusions is typically quantified using tracers of stratospheric origin in numerical models. On this basis, seven stratospheric $\mathrm{O}_{3}$ intrusions occurred in the western United States during the IONS2010 campaign in May-June 2010 (Cooper et al., 2011; Lin et al., 2012a, b). The four strongest intrusions occurred on 2224 May, 27-29 May, 7-8 June and 9-14 June (Lin et al., $2012 \mathrm{a}, \mathrm{b})$. Enhanced ozone mixing ratios in combination with very low relative humidity $(\mathrm{RH})$ provides a qualitative proxy for dry air of possible stratospheric origin. High isentropic potential vorticity (IPV) in the troposphere and high total ozone column (TOC) are other indicators of stratospheric air and tropopause folding. Figure 10 displays both IPV at $330 \mathrm{~K}$ and TOC fields over the western United States during 28 May and 10 June, when the strongest stratospheric intrusions occurred (source: ERA-Interim; Dee et al., 2011). Both fields demonstrate higher-than-normal values over the region during the examined periods. This result is also supported from the soundings at the six IONS sites (Fig. S6). Dry air masses with enhanced $\mathrm{O}_{3}$ are recorded at various levels, in spatial agreement with areas of enhanced TOC and IPV (Fig. 10). The periods of 28 May and 8-9 June 2010 are selected as the most representative of strong stratospheric intrusions, and the vertical ozone profiles for all models and stations are depicted in Fig. 11. On 28 May, the soundings show high ozone values (above 100-150 ppb) for the northern sites (TH, RY and $\mathrm{SH}$ ) in the $6-10 \mathrm{~km}$ range and for the southern sites (PS, SN and JT) in the $2-5 \mathrm{~km}$ range; these high ozone values coincide with a strong drop in RH. The high ozone mixing ratios are not captured by any model, except at Trinidad Head and Shasta $(\mathrm{SH})$. Similar performance is seen in the 9 June vertical profiles, where the models capture the vertical gradient of the ozone mixing ratios but not the high values seen in the northern sites, RY and PS (all vertical profiles are included in the Supplement, Fig. S6).

Meteorological fields are expected to influence the ozone production and distribution between the troposphere and stratosphere although the influence exerted to the ozone vertical profiles from meteorological fields is inherently nonlinear and thus difficult to link directly. A tropopause fold is typically identified by the presence of a very dry stable layer in the free atmosphere at potential temperatures around 310-320 K, which corresponds to the frontal zone beneath the polar jet stream (Vaughan et al., 1994). As an example, very dry layers were observed at 22, 27 and 28 May over around $8 \mathrm{~km}$ a.g.l. at RY (Fig. S6). At the same days, the range of potential temperatures $310-320 \mathrm{~K}$ was typically found at those heights (Fig. S7). Both facts combined explain the origin of the high ozone levels recorded on the $22 \mathrm{nd}$ and 27 th. The stratospheric intrusion was also simulated by 

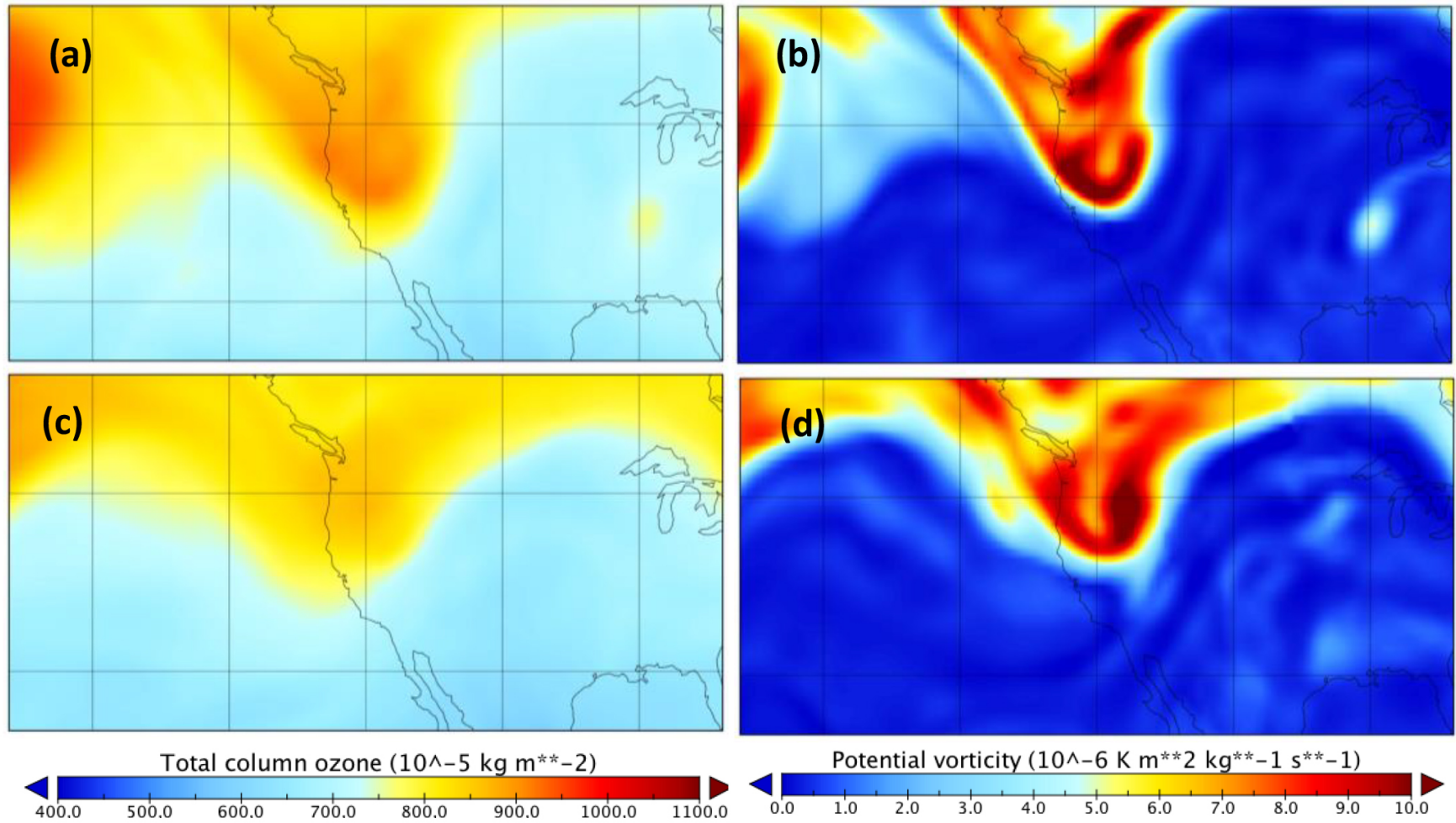

Potential vorticity $\left(10^{\wedge}-6 \mathrm{~K} \mathrm{~m}^{\star \star} 2 \mathrm{~kg}^{\star \star} \star-1 \mathrm{~s}^{* \star \star}-1\right)$

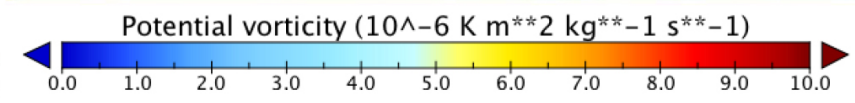

Figure 10. Indicative fields of total ozone column (TOC, a, c) and potential vorticity (IPV, b, d) at the $330 \mathrm{~K}$ isentropic surface during 28 May 2010 (a, b) and 10 June 2010 (c, d). Source: Era-Interim.

all models (Fig. S7), with varying intensity though. Models US1 and US3, which share the same meteorological driver, better represent the vertical extent of the ozone penetration. The isentropic isolines for US1 and US3 are in better agreement with the observed ridges in potential temperature during stratospheric intrusions.

We also calculated the aggregated fractional difference indicator across all stations (here aggregation denotes that FD is calculated for each individual profile and then averaged). The general model errors found earlier, such as the tendency for all models to overestimate mixing ratios in the first kilometer, are also evident in the FD plot (Fig. 12). Moreover, the tendency of some models to depart from the average error profile is also reproduced, such as the underestimation of DE1 between 1 and $2 \mathrm{~km}$ and the overestimations of DK1 in the 5-7 km layer. When calculating the FD at each site, it is found that the overestimation in the first kilometer occurs at all sites and has a latitudinal gradient across the coastal sites with larger values towards the south, which relates to the impact of the marine boundary layer. Above $5 \mathrm{~km}$, the bias also has a latitudinal gradient starting with negative values in the north (TH) and progressively becoming positive moving southwards. During episodic conditions, significant overestimations and underestimations are evident above $9 \mathrm{~km}$ at some sites (e.g., RY and PS in panel d). Those high FD values of both signs are found at the sites exhibiting strato- spheric intrusion signals in Fig. S6 (e.g., RY at 27 May, PS at 11 June), indicating that the stratosphere-troposphere exchange in the regional model and/or the C-IFS model providing boundary conditions may not be fully captured during these episodes. The performance of the modeling systems appears to be more closely linked to the meteorological driver rather than the actual air quality model. The two simulations using CMAQ (US3 and DE1) do not produce similar results at any of the sites, although they share the same BCs and emissions. In contrast, the CMAQ and CAMx simulations (US3 and US1 respectively) which share common meteorological fields, and thus the same PBL scheme (but use a different vertical resolution as noted by Liu et al., 2018), have rather similar results.

\section{Conclusions}

We analyze four annual air quality model simulations for North America performed under AQMEII3 to evaluate seasonal ozone vertical profiles for the year 2010 against ozonesonde observations. The objectives of this analysis are to (a) evaluate simulated seasonal ozone vertical profiles with ozonesonde measurements, (b) assess variations in model performance related to ozone vertical distribution (model inter-comparison), (c) assess the influence of lateral bound- 

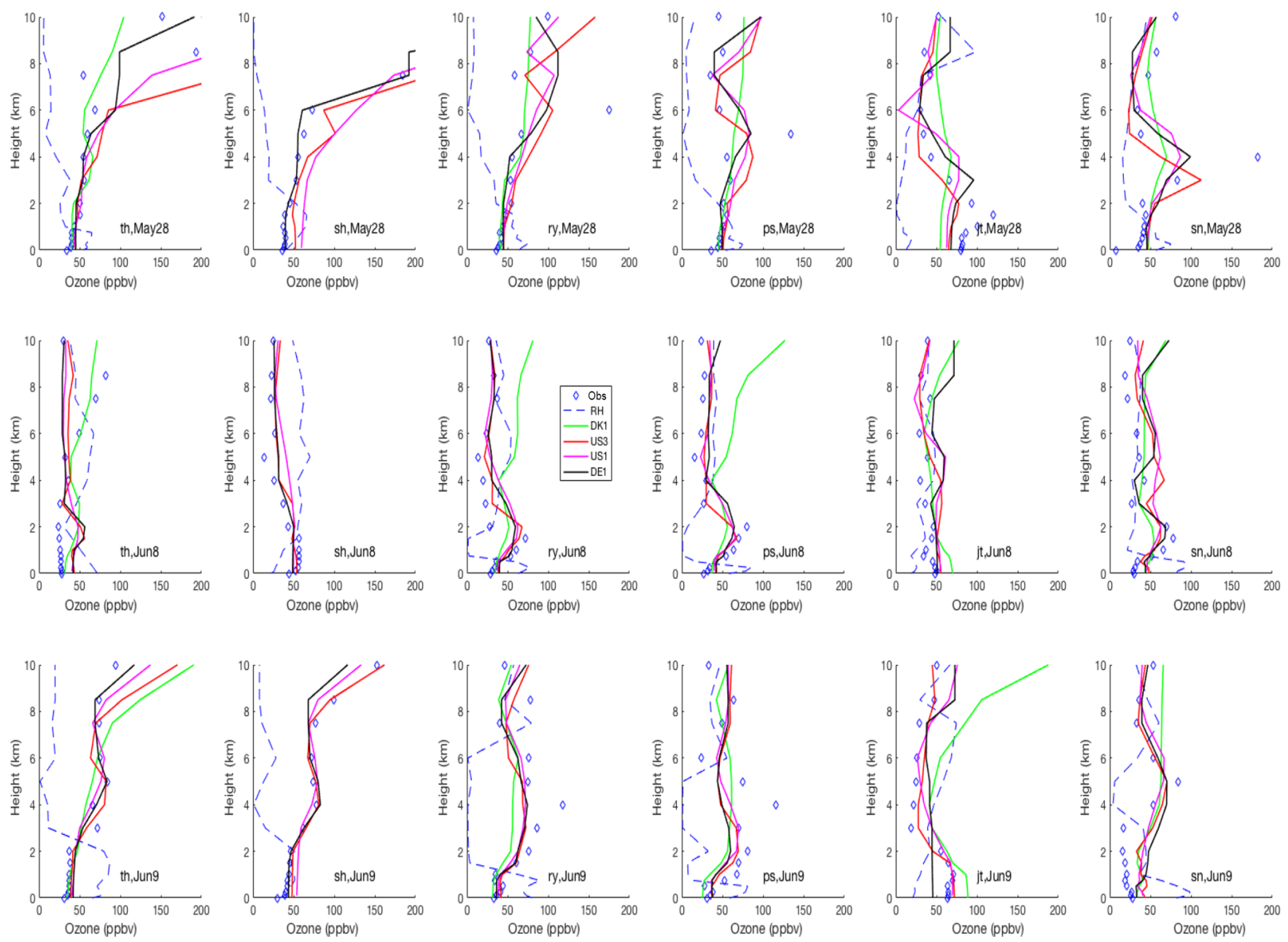

Figure 11. Ozone profiles (observed: diamond; modeled: colored lines) and relative humidity (dashed line in \%; shares the same scale with ozone in the $x$ axis) at each IONS site during the 28 May and 8-9 June intrusion. The stratospheric intrusion is denoted by the sudden drop in relative humidity that is accompanied by an increase in ozone mixing ratios from the ozonesondes.

ary conditions on ozone profiles within the modeling domain, and (d) investigate cases of stratospheric ozone intrusions in the western United States during May-June 2010.

The evaluation of the seasonal ozone profiles reveals that, at a majority of the stations, ozone mixing ratios are underestimated in the 1-6 km range. Model performance as measured by RMSE is better during winter and spring for the lower troposphere (LT, 0-2 km) and during summer and fall for the upper troposphere (UT; $2-8.5 \mathrm{~km}$ ). In general, the average RMSE over all stations for the LT increases for all models in the following order: winter, spring, fall, summer. Average RMSE for all stations and models during summer is $12 \mathrm{ppb}, 10 \mathrm{ppb}$ for the fall, and $8 \mathrm{ppb}$ for winter and spring. Average RMSE for all stations for the UT during spring is $33 \mathrm{ppb}: 26 \mathrm{ppb}$ for winter, $22 \mathrm{ppb}$ for summer and $15 \mathrm{ppb}$ for fall. There is a tendency for all models to agree on high UT errors for the Boulder site during winter and spring and for Huntsville and Trinidad Head during spring. For both LT and
UT, the same seasonal change noted in the RMSE is seen in the variance of ozone mixing ratios for both observations and model results, with the majority of the models exhibiting less variability than the observations. Even though the modeling systems differ in horizontal grid spacing, meteorological drivers and atmospheric vertical layers, it was not possible to connect model performance to these variations. The results show that the meteorological driver is more impactful compared to the air quality model, without specifically indicating that one driver is more skillful that the others.

The chemically inert tracers provide a relative assessment of influences of the lateral boundary conditions on ozone profiles. The results indicate that the lower-troposphere mixing ratios (LT) are influenced by both BC1 (lateral boundary set to nonzero below $750 \mathrm{hPa}$ ) and $\mathrm{BC} 2$ (lateral boundary set to nonzero between 750 and $250 \mathrm{hPa}$ ). The relative contributions of $\mathrm{BC} 1$ and $\mathrm{BC} 2$ depend on season and station location, with the $\mathrm{BC} 2$ contribution being stronger in the summer for 

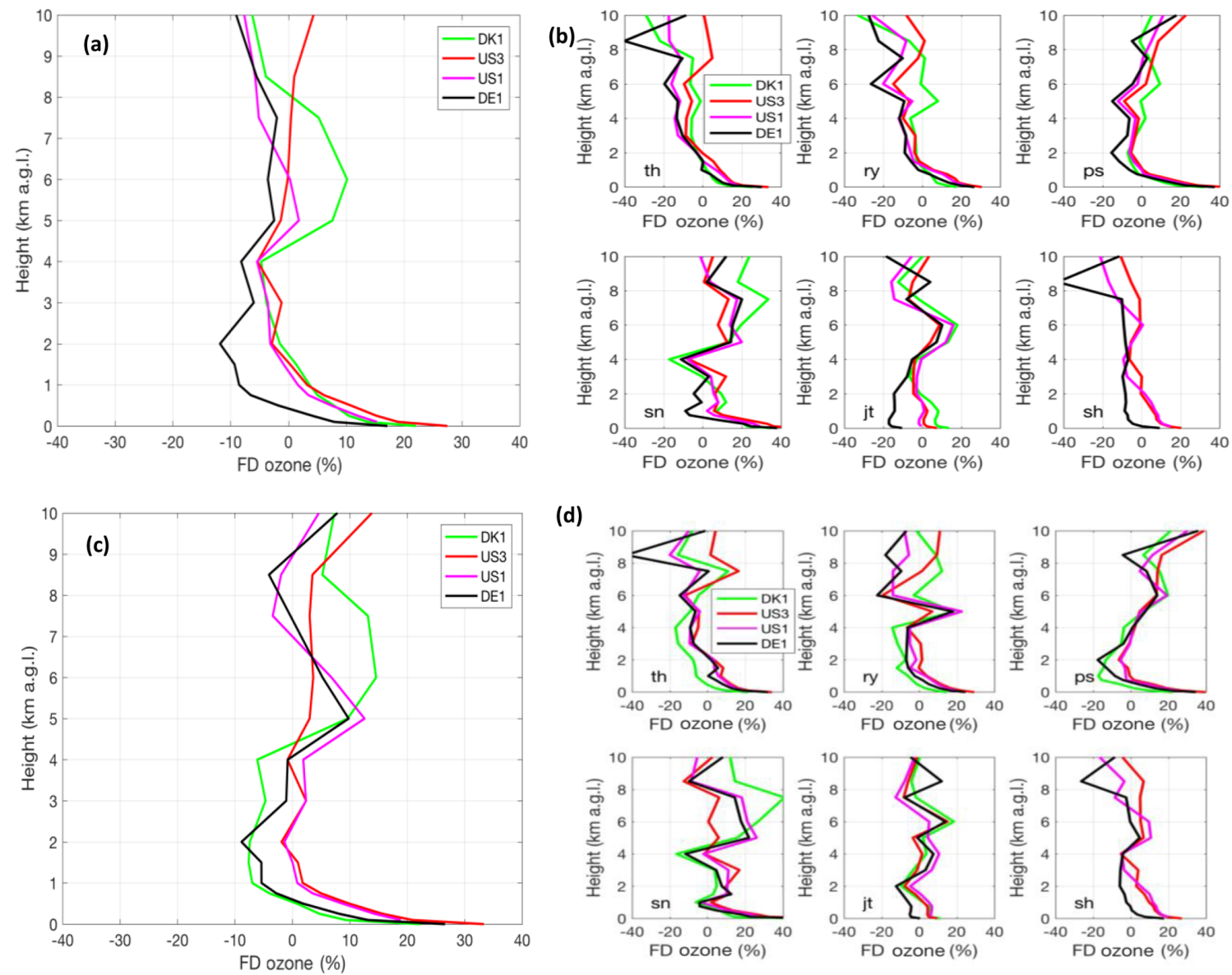

(d)
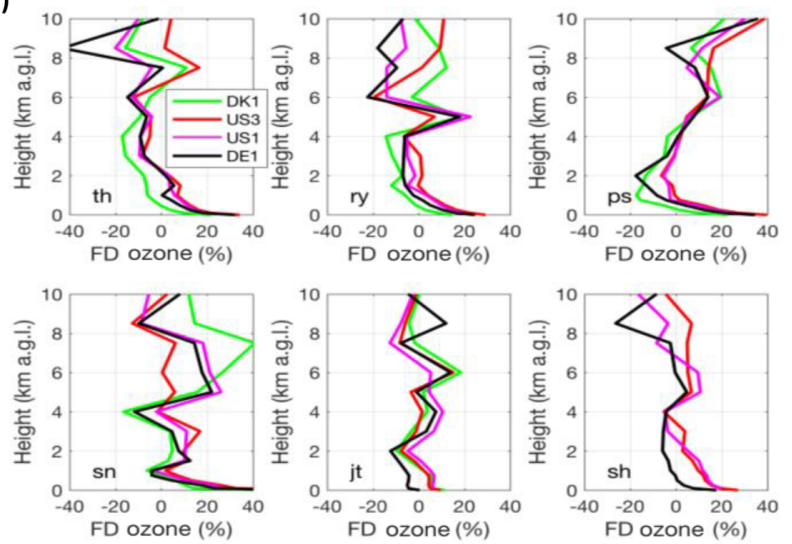

Figure 12. Fractional difference (\%) between observed and simulated ozone profiles. Results are presented aggregated from all soundings (a, c) and at each site separately (b, d). (a) and (b) use all profiles (10 May-20 June 2010). (c) and (d) present results during episodic conditions (22-29 May, 7-14 June). (FD is calculated for each individual profile and then averaged.)

all sites $(50 \%-85 \%)$ compared to $\mathrm{BC} 1$. This highlights the importance of lateral boundary conditions up to $250 \mathrm{hPa}$ for lower-tropospheric ozone mixing ratios $(0-2 \mathrm{~km})$. The middle troposphere mixing ratios are primarily influenced by the $\mathrm{BC} 2$ tracer with some contribution from $\mathrm{BC} 3$ (lateral boundary set to nonzero above $250 \mathrm{hPa}$ ). The upper-tropospherelower-stratosphere mixing ratios (UTLS) are almost exclusively influenced by the BC3 tracer for all seasons, models and sites.

For the stratospheric intrusion case study, the comparison of the four modeling systems against $\mathrm{O}_{3}$ soundings in California during May-June 2010 revealed that the models can reproduce the location and timing of most intrusions but underestimate the magnitude of the maximum mixing ratios in the $2-6 \mathrm{~km}$ range. There is a general tendency of the models to overestimate ozone mixing ratios in the $1 \mathrm{~km}$ layer adjacent to the surface and above $5 \mathrm{~km}$. The former is possibly related to inaccuracies in surface and/or PBL processes while the latter points to potential errors in boundary conditions and/or the representation of the exchange between the upper troposphere and the lower stratosphere in the regional models. The differences between the four modeling systems are mostly evident above $6 \mathrm{~km}$ and the choice of meteorological driver appears to be a greater predictor of model skill in this altitude range than the choice of air quality model.

Data availability. The modeling and observational data generated for the AQMEII Phase 3 are accessible through the ENSEMBLE data platform (http://ensemble.jrc.ec.europa.eu, last access: September 2017) upon contact with the managing organizations. The Joint Research Center Ispra's Institute for Environment and Sustainability provided its ENSEMBLE system for model output harmonization and analyses and evaluation.

Supplement. The supplement related to this article is available online at: https://doi.org/10.5194/acp-18-13925-2018-supplement.

Author contributions. MA and IK designed the analysis and wrote the manuscript with contributions from all co-authors; GAF and IK conducted the data analysis; JB, JC, UI, UN, GY, CH and PL were 
responsible for the numerical simulations; RB, ES and SG provided access to the ENSEMBLES system and data retrieval; ORC, IP, BJ and DWT are responsible for the ozonesonde data used in the study.

Competing interests. The authors declare that they have no conflict of interest.

Disclaimer. The views expressed in this article are those of the authors and do not necessarily represent the views or policies of the U.S. Environmental Protection Agency.

Special issue statement. This article is part of the special issue "Global and regional assessment of intercontinental transport of air pollution: results from HTAP, AQMEII and MICS". It is not associated with a conference.

Acknowledgements. We gratefully acknowledge the contribution of all research groups and organizations that provided the datasets used in this study: U.S. EPA (North American emissions processing and gridded meteorology); ECMWF MACC (chemical boundary conditions); the WMO World Ozone and Ultraviolet Data Centre (WOUDC) and its data-contributing agencies provided North American ozonesonde profiles; additional ozonesonde profiles were downloaded from NOAA's Earth System Research Laboratory, Global Monitoring Division (https://www.esrl.noaa.gov/, last access: September 2017).

Edited by: Martin Dameris

Reviewed by: three anonymous referees

\section{References}

Akritidis, D., Pozzer, A., Zanis, P., Tyrlis, E., Škerlak, B., Sprenger, M., and Lelieveld, J.: On the role of tropopause folds in summertime tropospheric ozone over the eastern Mediterranean and the Middle East, Atmos. Chem. Phys., 16, 14025-14039, https://doi.org/10.5194/acp-16-14025-2016, 2016.

Appel, K. W., Gilliland, A. B., Sarwar, G., and Gilliam, R. C.: Evaluation of the Community Multiscale Air Quality (CMAQ) model version 4.5: Sensitivities impacting model performance; Part I ozone, Atmos. Environ., 41, 9603-9615, 2007.

Appel, W., Chemel, C., Roselle, S. J., Francis, X. V., Hu, R.-M., Sokhi, R. S., Rao, S. T., and Galmarini, S.: Examination of the Community Multiscale Air Quality (CMAQ) model performance for North America and Europe for the AQMEII project, Atmos. Environ., 53, 142-155, 2012.

Baker, K., Emery, C., Dolwick, P., and Yarwood, G.: Photochemical grid model estimates of lateral boundary contributions to ozone and particulate matter across the continental United States, Atmos. Environ., 123, 49-62, 2015.

Chevalier, A., Gheusi, F., Delmas, R., Ordóñez, C., Sarrat, C., Zbinden, R., Thouret, V., Athier, G., and Cousin, J.-M.: Influence of altitude on ozone levels and variability in the lower troposphere: a ground-based study for western Europe over the period 2001-2004, Atmos. Chem. Phys., 7, 4311-4326, https://doi.org/10.5194/acp-7-4311-2007, 2007.

Cooper, O. R., Oltmans, S. J., Johnson, B. J., Brioude, J., Angevine, W., Trainer, M., Parrish, D. D., Ryerson, T. R., Pollack, I., Cullis, P. D., Ives, M. A., Tarasick, D. W., AlSaadi, J., and Stajner, I.: Measurement of western U.S. baseline ozone from the surface to the tropopause and assessment of downwind impact regions, J. Geophys. Res., 116, D00V03, https://doi.org/10.1029/2011JD016095, 2011.

Cooper, O. R., Gao, R.-S., Tarasick, D., Leblanc, T., and Sweeney, C.: Long-term ozone trends at rural ozone monitoring sites across the United States, 1990-2010, J. Geophys. Res., 117, D22307, https://doi.org/10.1029/2012JD018261, 2012.

Dee, D. P., Uppala, S. M., Simmons, A. J., Berrisford, P., Poli, P., Kobayashi, S., Andrae, U., Balmaseda, M. A., Balsamo, G., Bauer, P., Bechtold, P., Beljaars, A. C. M., van de Berg, L., Bidlot, J., Bormann, N., Delsol, C., Dragani, R., Fuentes, M., Geer, A. J., Haimberger, L., Healy, S. B., Hersbach, H., Hólm, E. V., Isaksen, L., Kållberg, P., Köhler, M., Matricardi, M., McNally, A. P., Monge-Sanz, B. M., Morcrette, J.-J., Park, B.-K., Peubey, C., de Rosnay, P., Tavolato, C., Thépaut, J.-N., and Vitart, F.: The ERA-Interim reanalysis: configuration and performance of the data assimilation system, Q. J. Roy. Meteorol. Soc., 137, 553597, https://doi.org/10.1002/qj.828, 2011.

Efron, B.: Better bootstrap confidence intervals, J. Amer. Stat. Assoc., 82, 171-185, 1987.

Flemming, J., Huijnen, V., Arteta, J., Bechtold, P., Beljaars, A., Blechschmidt, A.-M., Diamantakis, M., Engelen, R. J., Gaudel, A., Inness, A., Jones, L., Josse, B., Katragkou, E., Marecal, V., Peuch, V.-H., Richter, A., Schultz, M. G., Stein, O., and Tsikerdekis, A.: Tropospheric chemistry in the Integrated Forecasting System of ECMWF, Geosci. Model Dev., 8, 975-1003, https://doi.org/10.5194/gmd-8-975-2015, 2015.

Galmarini, S. and Rao, S. T.: The AQMEII two-continent Regional Air Quality Model evaluation study: Fueling ideas with unprecedented data, Atmos. Environ., 45, 2464, https://doi.org/10.1016/j.atmosenv.2011.03.025, 2011.

Galmarini, S., Koffi, B., Solazzo, E., Keating, T., Hogrefe, C., Schulz, M., Benedictow, A., Griesfeller, J. J., JanssensMaenhout, G., Carmichael, G., Fu, J., and Dentener, F.: Technical note: Coordination and harmonization of the multi-scale, multi-model activities HTAP2, AQMEII3, and MICS-Asia3: simulations, emission inventories, boundary conditions, and model output formats, Atmos. Chem. Phys., 17, 1543-1555, https://doi.org/10.5194/acp-17-1543-2017, 2017

Giordano, L., Brunner, D., Flemming, J., Hogrefe, C., Im, U., Bianconi, R., Badia, A., Balzarini, A., Baro, R., Chemel, C., Curci, G., Forkel, R., Jimenez-Guerrero, P., Hirtl, M., Hodzic, A., Honzak, L., Jorba, O., Knote, C., Kuenen, J. J. P., Makar, P. A., MandersGroot, A., Neal, L., Perez, J. L., Pirovano, G., Pouliot, G., San Jose, R., Savage, N., Schroder,W., Sokhi, R. S., Syrakov, D., Torian, A., Tuccella, P., Werhahn, J., Wolke, R., Yahya, K., Žabkar, R., Zhang, Y., and Galmarini, S.: Assessment of the MACC reanalysis and its influence as chemical boundary conditions for regional air quality modelling in AQMEII-2, Atmos. Environ., 115, 371-388, 2015.

Herwehe, J. A., Otte, T. L., Mathur, R., and Trivikrama Rao, S.: Diagnostic analysis of ozone concentrations simulated by two 
regional-scale air quality models, Atmos. Environ., 45, 59575969, 2011.

Hogrefe, C., Rao, S. T., Kasibhatla, P., Hao, W., Sistla, G., Mathur, R., and McHenry, J.: Evaluating the performance of regionalscale photochemical modeling systems: Part II - ozone predictions, Atmos. Environ., 35, 4175-4188, 2001.

Hogrefe, C., Liu, P., Pouliot, G., Mathur, R., Roselle, S., Flemming, J., Lin, M., and Park, R. J.: Impacts of different characterizations of large-scale background on simulated regional-scale ozone over the continental United States, Atmos. Chem. Phys., 18, 3839-3864, https://doi.org/10.5194/acp-18-3839-2018, 2018.

Huang, M., Carmichael, G. R., Pierce, R. B., Jo, D. S., Park, R. J., Flemming, J., Emmons, L. K., Bowman, K. W., Henze, D. K., Davila, Y., Sudo, K., Jonson, J. E., Tronstad Lund, M., Janssens-Maenhout, G., Dentener, F. J., Keating, T. J., Oetjen, H., and Payne, V. H.: Impact of intercontinental pollution transport on North American ozone air pollution: an HTAP phase 2 multi-model study, Atmos. Chem. Phys., 17, 5721-5750, https://doi.org/10.5194/acp-17-5721-2017, 2017.

Im, U., Bianconi, R., Solazzo, E., Kioutsioukis, I., Badia, A., Balzarini, A., Baro, R., Belassio, R., Brunner, D., Chemel, C., Curci, G., Flemming, J., Forkel, R., Giordano, L., JimenezGuerrero, P., Hirtl, M., Hodzic, A., Honzak, L., Jorba, O., Knote, C., Kuenen, J. J. P., Makar, P. A., Manders-Groot, A., Neal, L., Perez, J. L., Piravano, G., Pouliot, G., San Jose, R., Savage, N., Schroder, W., Sokhi, R. S., Syrakov, D., Torian, A., Werhahn, K., Wolke, R., Yahya, K., Zabkar, R., Zhang, Y., Zhang, J., Hogrefe, C., and Galmarini, S.: Evaluation of operational online-coupled regional air quality models over Europe and North America in the context of AQMEII phase 2. Part I: Ozone, Atmos. Environ., 115, 404-420, 2015.

Im, U., Christensen, J. H., Geels, C., Hansen, K. M., Brandt, J., Solazzo, E., Alyuz, U., Balzarini, A., Baro, R., Bellasio, R., Bianconi, R., Bieser, J., Colette, A., Curci, G., Farrow, A., Flemming, J., Fraser, A., Jimenez-Guerrero, P., Kitwiroon, N., Liu, P., Nopmongcol, U., Palacios-Peña, L., Pirovano, G., Pozzoli, L., Prank, M., Rose, R., Sokhi, R., Tuccella, P., Unal, A., Vivanco, M. G., Yarwood, G., Hogrefe, C., and Galmarini, S.: Influence of anthropogenic emissions and boundary conditions on multi-model simulations of major air pollutants over Europe and North America in the framework of AQMEII3, Atmos. Chem. Phys., 18, 89298952, https://doi.org/10.5194/acp-18-8929-2018, 2018.

Janjic, Z. I.: The Step-Mountain Eta Coordinate Model: Further Developments of the Convection, Viscous Sublayer, and Turbulence Closure Schemes, Mon. Weather Rev., 122, 927-945, 1994.

Jonson, J. E., Stohl, A., Fiore, A. M., Hess, P., Szopa, S., Wild, O., Zeng, G., Dentener, F. J., Lupu, A., Schultz, M. G., Duncan, B. N., Sudo, K., Wind, P., Schulz, M., Marmer, E., Cuvelier, C., Keating, T., Zuber, A., Valdebenito, A., Dorokhov, V., De Backer, H., Davies, J., Chen, G. H., Johnson, B., Tarasick, D. W., Stübi, R., Newchurch, M. J., von der Gathen, P., Steinbrecht, W., and Claude, H.: A multi-model analysis of vertical ozone profiles, Atmos. Chem. Phys., 10, 5759-5783, https://doi.org/10.5194/acp10-5759-2010, 2010.

Kioutsioukis, I. and Galmarini, S.: De praeceptis ferendis: good practice in multi-model ensembles, Atmos. Chem. Phys., 14, 11791-11815, https://doi.org/10.5194/acp-14-11791-2014, 2014.
Kioutsioukis, I., Im, U., Solazzo, E., Bianconi, R., Badia, A., Balzarini, A., Baró, R., Bellasio, R., Brunner, D., Chemel, C., Curci, G., van der Gon, H. D., Flemming, J., Forkel, R., Giordano, L., Jiménez-Guerrero, P., Hirtl, M., Jorba, O., MandersGroot, A., Neal, L., Pérez, J. L., Pirovano, G., San Jose, R., Savage, N., Schroder, W., Sokhi, R. S., Syrakov, D., Tuccella, P., Werhahn, J., Wolke, R., Hogrefe, C., and Galmarini, S.: Insights into the deterministic skill of air quality ensembles from the analysis of AQMEII data, Atmos. Chem. Phys., 16, 15629-15652, https://doi.org/10.5194/acp-16-15629-2016, 2016.

Langford, A. O., Alvarez, R. J., Brioude, J., Evan, S., Iraci, L. T., Kirgis, G., Kuang, S., Leblanc, T., Newchurch, M. J., Pierce, R. B., Senff, C. J., and Yates, E. L.: Coordinated profiling of stratospheric intrusions and transported pollution by the Tropospheric Ozone Lidar Network (TOLNet) and NASA Alpha Jet experiment (AJAX): Observations and comparison to HYSPLIT, RAQMS, and FLEXPART, Atmos. Environ., 174, 1-14, https://doi.org/10.1016/j.atmosenv.2017.11.031, 2018.

Lin, M., Fiore, A. M., Cooper, O. R., Horowitz, L. W., Langford, A. O., Levy II, H., Johnson, B. J., Naik, V., Oltmans, S. J., and Senff, C. J.: Springtime high surface ozone events over the western United States: Quantifying the role of stratospheric intrusions, J. Geophys. Res., 117, D00V22, https://doi.org/10.1029/2012JD018151, 2012a.

Lin, M. Y., Fiore, M., Horowitz, L. W., Cooper, O. R., Naik, V., Holloway, J., Johnson, B. J., Middlebrook, A. M., Oltmans, S., J., Pollack, I. B., Ryerson, T. B., Warner, J. X., Wiedinmyer, C., Wilson, J., and Wyman, B.: Transport of Asian ozone pollution into surface air over the western United States in spring, J. Geophys. Res.-Atmos., 117, D00V07, https://doi.org/10.1029/2011JD016961, 2012b.

Lin, M., Horowitz, L. W., Cooper, O. R., Tarasick, D., Conley, S., Iraci, L. T., Johnson, B., Leblanc, T., Petropavlovskikh, I., and Yates, E. L.: Revisiting the evidence of increasing springtime ozone mixing ratios in the free troposphere over western North America, Geophys. Res. Lett., 42, 8719-8728, https://doi.org/10.1002/2015GL065311, 2015.

Liu, G., Liu, J., Tarasick, D. W., Fioletov, V. E., Jin, J. J., Moeini, O., Liu, X., Sioris, C. E., and Osman, M.: A global tropospheric ozone climatology from trajectory-mapped ozone soundings, Atmos. Chem. Phys., 13, 10659-10675, https://doi.org/10.5194/acp-13-10659-2013, 2013.

Liu, P., Hogrefe, C., Im, U., Christensen, J. H., Bieser, J., Nopmongcol, U., Yarwood, G., Mathur, R., Rosselle, S., and Spero, T.: Multi-Model Comparison in the Impact of Lateral Boundary Conditions on Simulated Surface Ozone across the United States Using Chemically Inert Tracers, Atmos. Chem. Phys. Discuss., https://doi.org/10.5194/acp-2018-106, in review, 2018.

Makar, P. A., Gong, W., Mooney, C., Zhang, J., Davignon, D., Samaali, M., Moran, M. D., He, H., Tarasick, D. W., Sills, D., and Chen, J.: Dynamic adjustment of climatological ozone boundary conditions for air-quality forecasts, Atmos. Chem. Phys., 10, 8997-9015, https://doi.org/10.5194/acp-10-8997-2010, 2010.

Nopmongcol, U., Liu, Z., Stoeckenius, T., and Yarwood, G.: Modeling intercontinental transport of ozone in North America with CAMx for the Air Quality Model Evaluation International Initiative (AQMEII) Phase 3, Atmos. Chem. Phys., 17, 9931-9943, https://doi.org/10.5194/acp-17-9931-2017, 2017. 
Pendlebury, D., Gravel, S., Moran, M. D., and Lupu, A.: Impact of chemical lateral boundary conditions in a regional air quality forecast model on surface ozone predictions during stratospheric intrusions, Atmos. Environ., 174, 148-170, https://doi.org/10.1016/j.atmosenv.2017.10.052, 2017.

Pleim, J. E.: A Combined Local and Nonlocal Closure Model for the Atmospheric Boundary Layer, Part II: application and evaluation in a mesoscale meteorological model, J. Appl. Meteorol. Clim., 46, 1396-1409, 2007.

Pouliot, G., Denier van der Gon, H. A. C., Kuenen, J., Zhang, J., Moran, M. D., and Makar, P. A.: Analysis of the emission inventories and model-ready emission datasets of Europe and North America for phase 2 of the AQMEII project, Atmos. Environ., 115, 345-360, https://doi.org/10.1016/j.atmosenv.2014.10.061, 2015.

Rao, S. T., Mathur, R., Hogrefe, C., Keating, T., Dentener, F., and Galmarini, S.: Path forward, EM, Air and Waste Management Association's Magazine for Environmental Managers, 2012.

Ryerson, T. B., Andrews, A. E., Angevine, W. M., Bates, T. S., Brock, C. A., Cairns, B., Cohen, R. C., Cooper, O. R., de Gouw, J. A., Fehsenfeld, F. C., Ferrare, R. A., Fischer, M. L., Flagan, R. C., Goldstein, A. H., Hair, J. W., Hardesty, R. M., Hostetler, C. A., Jimenez, J. L., Langford, A. O., McCauley, E., McKeen, S. A., Molina, L. T., Nenes, A., Oltmans, S. J., Parrish, D. D., Pederson, J. R., Pierce, R. B., Prather, K., Quinn, P. K., Seinfeld, J. H., Senff, C. J., Sorooshian, A., Stutz, J., Surratt, J. D., Trainer, M., Volkamer, R., Williams, E. J., and Wofsy, S. C.: The 2010 California Research at the Nexus of Air Quality and Climate Change (CalNex) field study, J. Geophys. Res., 118, 5830 5866, https://doi.org/10.1002/jgrd.50331, 2013.

Schere, K., Flemming, J., Vautard, R., Chemel, C., Colette, A., Hogrefe, C., Bessagnet, B., Meleux, F., Mathur, R., Roselle, S., Hu, R., Sokhi, R. S., Rao, S. T., and Galmarini, S.: Trace gas/aerosol boundary concentrations and their impacts on continental-scale AQMEII modeling domains, Atmos. Environ., 53, 38-50, https://doi.org/10.1016/j.atmosenv.2011.09.043, 2012.

Solazzo, E., Bianconi, R., Vautard, R., Wyat Appel, K., Moran, M. D., Hogrefe, C., Bessagnet, B., Brandt, J., Christensen, J. H., Chemelk, C., Coll, I., Denier van der Gon, H., Ferreira, J., Forkel, R., Francis, X. V., Grell, G., Grossi, P., Hansen, A. B., Jeričević, A., Kraljeviv'c, L., Miranda, A. I., Nopmongcol, U., Pirovanof, G., Prank, M., Riccio, A., Sartelet, K. N., Schaap, M., Silver, J. D., Sokhi, R. S., Vira, J., Werhahn, J., Wolke, R., Yarwood, G., Zhang, J., Rao, S. T., and Galmarini, S.: Model evaluation and ensemble modelling of surface-level ozone in Europe and North America in the context of AQMEII, Atmos. Environ., 53, 60-74, 2012.
Solazzo, E., Bianconi, R., Pirovano, G., Moran, M. D., Vautard, R., Hogrefe, C., Appel, K. W., Matthias, V., Grossi, P., Bessagnet, B., Brandt, J., Chemel, C., Christensen, J. H., Forkel, R., Francis, X. V., Hansen, A. B., McKeen, S., Nopmongcol, U., Prank, M., Sartelet, K. N., Segers, A., Silver, J. D., Yarwood, G., Werhahn, J., Zhang, J., Rao, S. T., and Galmarini, S.: Evaluating the capability of regional-scale air quality models to capture the vertical distribution of pollutants, Geosci. Model Dev., 6, 791-818, https://doi.org/10.5194/gmd-6-791-2013, 2013.

Solazzo, E., Bianconi, R., Hogrefe, C., Curci, G., Tuccella, P., Alyuz, U., Balzarini, A., Baró, R., Bellasio, R., Bieser, J., Brandt, J., Christensen, J. H., Colette, A., Francis, X., Fraser, A., Vivanco, M. G., Jiménez-Guerrero, P., Im, U., Manders, A., Nopmongcol, U., Kitwiroon, N., Pirovano, G., Pozzoli, L., Prank, M., Sokhi, R. S., Unal, A., Yarwood, G., and Galmarini, S.: Evaluation and error apportionment of an ensemble of atmospheric chemistry transport modeling systems: multivariable temporal and spatial breakdown, Atmos. Chem. Phys., 17, 3001-3054, https://doi.org/10.5194/acp-17-3001-2017, 2017.

Stohl, A., Bonasoni, P., Cristofanelli, P., Collins, W., Feichter, J., Frank, A., Forster, C., Gerasopoulos, E., Gaggeler, H., James, P., Kentarchos, T., Kromp-Kolb, H., Kruger, B., Land, C., Meloen, J., Papayannis, A., Priller, A., Seibert, P., Sprenger, M., Roelofs, G. J., Scheel, H. E., Schnabel, C., Siegmund, P., Tobler, L., Trickl, T., Wernli, H., Wirth, V., Zanis, P., and Zerefos, C.: Stratosphere-troposphere exchange: A review, and what we have learned from STACCATO, J. Geophys. Res., 108, 8516, https://doi.org/10.1029/2002JD002490, 2003.

Tarasick, D. W., Moran, M. D., Thompson, A. M., Carey-Smith, T., Rochon, Y., Bouchet, V. S., Gong, W., Makar, P. A., Stroud, C., Ménard, S., Crevier, L.-P., Cousineau, S., Pudykiewicz, J. A., Kallaur, A., Moffet, R., Ménard, R., Robichaud, A., Cooper, O. R., Oltmans, S. J., Witte, J. C., Forbes, G., Johnson, B. J., Merrill, J., Moody, J. L., Morris, G., Newchurch, M. J., Schmidlin, F. J., and Joseph, E.: Comparison of Canadian air quality forecast models with tropospheric ozone profile measurements above midlatitude North America during the IONS/ICARTT campaign: Evidence for stratospheric input, J. Geophys. Res., 112, D12S22, https://doi.org/10.1029/2006JD007782, 2007.

Thompson, A. M., Stone, J. B., Witte, J. C., Miller, S. K., Oltmans, S. J., Kucsera, T. L., Ross, K. L., Pickering, K. E., Merrill, J. T., Forbes, G., Tarasick, D. W., Joseph, E., Schmidlin, F. J., McMillan, W. W., Warner, J., Hintsa, E. J., and Johnson, J. E.: Intercontinental Chemical Transport Experiment Ozonesonde Network Study (IONS) 2004: 1. Summertime upper troposphere/lower stratosphere ozone over northeastern North America, J. Geophys. Res., 112, D12S12, https://doi.org/10.1029/2006JD007441, 2007.

Vaughan, G., Price, J. D., and Howells, A.: Transport into the troposphere in a tropopause fold, Q. J. Roy. Meteorol. Soc., 120, 1085-1103, https://doi.org/10.1002/qj.49712051814, 1994. 